\title{
Analysis of DNA Methylation Status in Bodily Fluids for Early Detection of Cancer
}

\author{
Keigo Yokoi, Keishi Yamashita and Masahiko Watanabe * \\ Department of Surgery, Kitasato University School of Medicine, Kitasato, 1-15-1, Minami-ku, Sagamihara, \\ Kanagawa 252-0374, Japan; butterdog@woody.ocn.ne.jp (K.Yo.); keishi23@med.kitasato-u.ac.jp (K.Ya.) \\ * Correspondence: gekaw@med.kitasato-u.ac.jp; Tel.: +81-42-778-8111; Fax: +81-42-778-9556
}

Academic Editor: William Chi-shing Cho

Received: 22 January 2017; Accepted: 26 March 2017; Published: 30 March 2017

\begin{abstract}
Epigenetic alterations by promoter DNA hypermethylation and gene silencing in cancer have been reported over the past few decades. DNA hypermethylation has great potential to serve as a screening marker, a prognostic marker, and a therapeutic surveillance marker in cancer clinics. Some bodily fluids, such as stool or urine, were obtainable without any invasion to the body. Thus, such bodily fluids were suitable samples for high throughput cancer surveillance. Analyzing the methylation status of bodily fluids around the cancer tissue may, additionally, lead to the early detection of cancer, because several genes in cancer tissues are reported to be cancer-specifically hypermethylated. Recently, several studies that analyzed the methylation status of DNA in bodily fluids were conducted, and some of the results have potential for future development and further clinical use. In fact, a stool DNA test was approved by the U.S. Food and Drug Administration (FDA) for the screening of colorectal cancer. Another promising methylation marker has been identified in various bodily fluids for several cancers. We reviewed studies that analyzed DNA methylation in bodily fluids as a less-invasive cancer screening.
\end{abstract}

Keywords: methylation; cancer; screening; bodily fluid

\section{Introduction}

In prior decades, many studies have reported epigenetic aberrations in cancer. DNA hypermethylation of the promoter region of specific genes are a major epigenetic change, where some of the cancer-specific methylation genes are tumor suppressor genes. They could be used as molecular markers for the early detection of cancer, prognostic markers, and as therapeutic surveillance markers in cancer therapy [1-5].

Several methods for cancer screening, such as fecal occult blood test (FOBT) in colorectal cancer (CRC), prostate specific antigens (PSA) in prostate cancer, and urine cytology in bladder cancer, are applied clinically. However, most of these methods need improvements due to insufficient sensitivity or specificity. For the purpose of improving these weak points, more invasive methods, such as a colonoscopy or cystoscopy, are used; however, they are not acceptable for high throughput screening due to their invasiveness, technical difficulties, and expensive costs. More sensitive and specific, as well as less invasive methods, with sufficient cost-performance effectiveness, are highly expected to detect cancer cells at an early stage.

In recent years, there has been great progress in the analysis of circulating tumor DNA (ctDNA) in blood. Several studies have shown that the blood of patients with cancer contains cell-free DNA, which shows cancer-related molecular changes [6-8]. The origin of ctDNA was not only from circulating tumor cells. The amount of ctDNA was much larger than expected if its origins were lyses from circulating tumor cell [9]. Moreover, Bettegowda et al. [10] reported that ctDNA was often present in patients without detectable circulating tumor cells. These facts suggest another origin of ctDNA. Today, 
many studies suggest that the main origin of ctDNA is apoptotic and necrotic tumor cells [9,11-13]. Several studies have shown the usability of ctDNA, not only for cancer detection, but also for tumor monitoring, prognosis prediction, and early detection of recurrence [8,10,14-17]. From this point of view, ctDNA analysis demonstrates its usability in dynamic monitoring procedures because ctDNA can be repeatedly obtained, even after the primary tumor has been resected. As the first screening tool for cancer detection, ctDNA analysis is not fully appropriate; the method required to detect cancer-derived DNA alterations from ctDNA in serum or plasma uses highly technique-intensive tools, such as digital polymerase chain reaction (PCR) or next generation sequencers, in which the detection level is up to $1 / 100,000$, while prevalent tools, such as TaqMan PCR, can reach detection levels of $1 / 1000[3,18]$. Indeed, such advanced methods cannot be performed in many laboratories around the world at present. Furthermore, as many excellent review articles describing ctDNA in blood have already been made available $[11,19,20]$, we will not include them in this review.

There have been several studies, using different methods, which reported cancer specific DNA methylation in bodily fluids around the primary tumor (stool of CRC patients, urine of bladder cancer patients, etc.). Some of the results were very promising and have been approved in standard clinics. Detection of DNA methylation in bodily fluids using classical methods such as quantitative methylation specific PCR, has remained a promising theme. In this article, we reviewed studies that analyzed DNA methylation in less-invasively-obtainable bodily fluids, such as saliva, sputum, stool, and urine; however, we did not include blood. All studies we reviewed focus on promoter hypermethylation, but not the methylation of other genomic regions.

\section{Methods Used in Methylation Analyses}

\subsection{Sodium Bisulfite Treatment}

Most of the studies we reviewed used PCR-based techniques for methylation analyses. Methylated or unmethylated cytosines were not distinguished by DNA polymerase, thus, the information on epigenetic changes in DNA is lost through the PCR process. Therefore, some modification should be done to distinguish methylated or unmethylated cytosines. By using the bisulfite treatment technique, unmethylated cytosines were converted to uracil, while the methylated cytosines remained unchanged (Figure 1a). If this technique is performed under appropriate conditions, about $99 \%$ of unmethylated cytosines are expected to be converted to uracil [21,22]. During subsequent PCR, uracil residues are replaced to thymine residues. Whether the original cytosines were methylated or unmethylated could be analyzed after bisulfite treatment using each of the PCR-based techniques.

\subsection{Bisulfite Sequence Analyses}

Sequence analyses of bisulfite-treated DNA are the simplest method to analyze the methylation status of individual CpG sites. This method was first performed by Frommer et al. [23]. Bisulfite-treated DNA samples are amplified with PCR, and the PCR products are sequenced directly, or sequenced after cloning procedures. Direct sequence analyses of PCR products can determine the average figures of individual CPG sites, while cloned sequence analyses can obtain information from each specific molecule, regarding whether a CPG site is methylated or unmethylated (Figure 1b). For these reasons, direct sequence analyses are performed to screen the major propensity of the DNA methylation status, and cloned sequence analyses are performed for the sake an accurate confirmation of methylation status, even down to single molecules. Quantitative analyses cannot be done via direct sequence analyses, however, and cloned sequence analyses require too much time and money. Thus, for cancer screening, bisulfite sequence analysis is not an appropriate method.

\subsection{Pyrosequencing}

Pyrosequencing analysis is a broadly-used method for quantitative methylation analysis. Bisulfite-treated DNA was amplified by PCR and analyzed using a pyrosequencer. Using this method, 
each CpG site was quantitatively analyzed for its methylation status (Figure 1c). This method, however, can only analyze a small range of $\mathrm{CpG}$ sites, and also requires a cloning procedure. Furthermore, its throughput is lower than the methylation-specific PCR method, and, thus, is not fully appropriate for cancer screening.

a
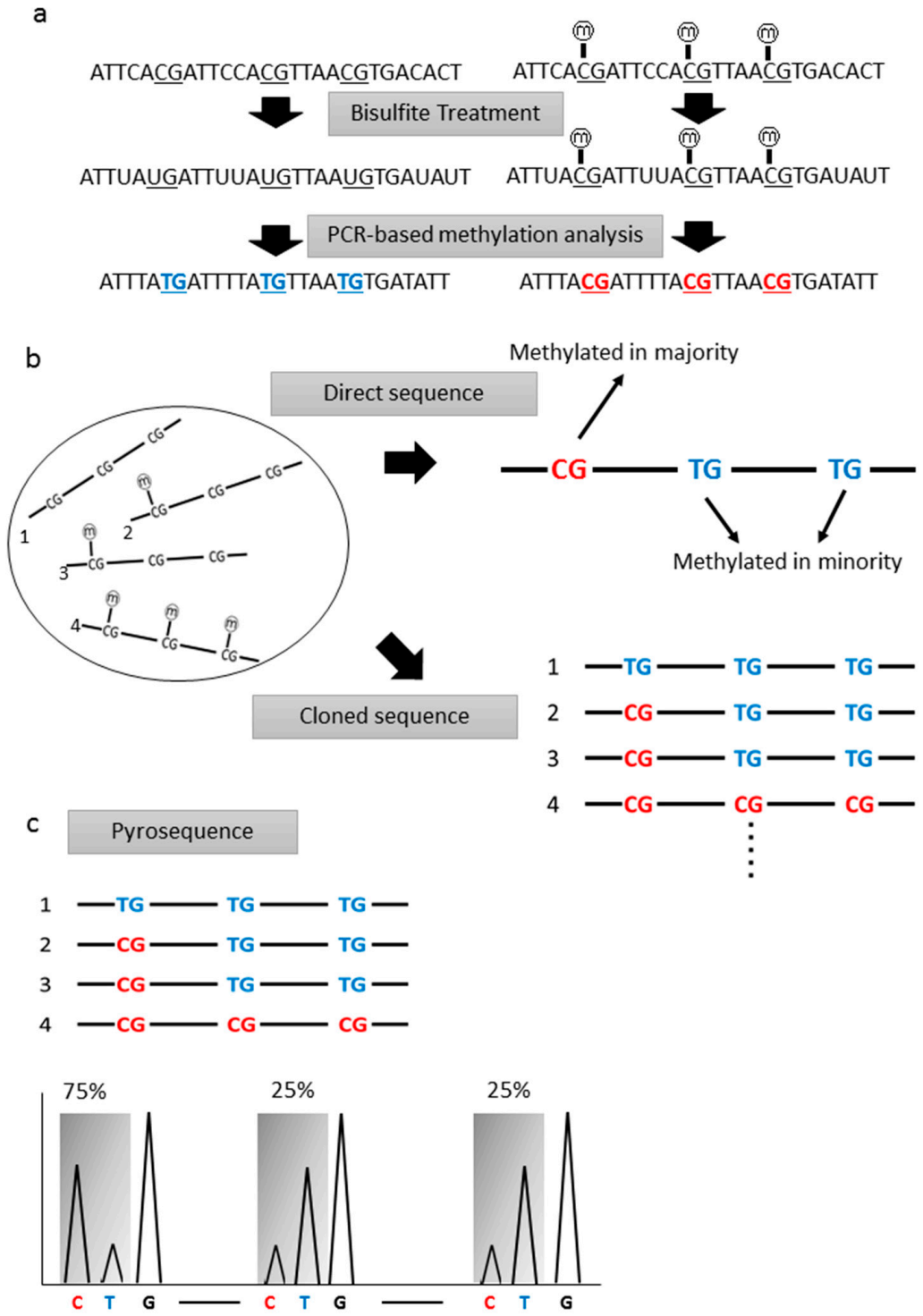

Figure 1. (a) A schema of bisulfite treatment of the sample DNA. Unmethylated cytosines were converted to uracil; (b) The difference between direct sequence and cloned sequence analyses. Average information of methylation status of each $\mathrm{CpG}$ site could be obtained by direct sequence and exact information of each single molecule about each $\mathrm{CpG}$ site could be obtained by cloned sequence analysis; (c) A schema of pyrosequence analysis. The ratio of methylated molecules could be analyzed using pyrosequence analysis.

\subsection{Methylation-Specific Polymerase Chain Reaction (PCR)}

Methylation-specific PCR (MSP) is the most common method in early studies of methylation analyses. MSP was first reported in 1996 by Herman et al. [24]. This method requires U-primer (primes designed to recognize unmethylated CpGs) and M-primer (primers designed to recognize methylated CpGs) (Figure 2a). M-primers contain several CpG sites (usually one to three in each primer sequence) and, thus, a high specificity for methylation is achieved. Although these are not quantitative 
methods, high throughput qualitative analyses can be done with a higher sensitivity. Herman et al. [24] developed this method and they reported that MSP could detect methylated templates with a sensitivity of $0.1 \%$ in a background of unmethylated templates. However, this conventional MSP has the problem of relatively-frequent, false positive results, especially when performed using a large numbers of PCR cycles [21].

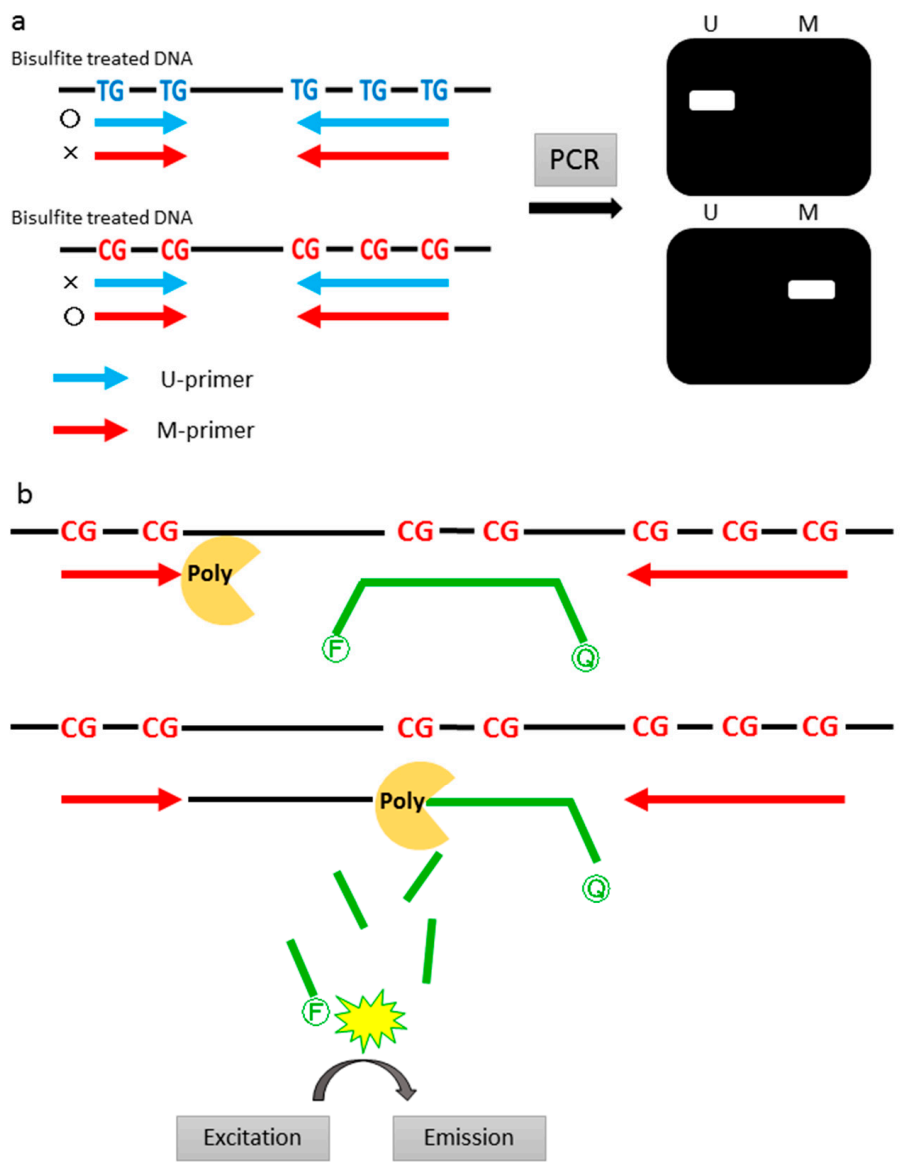

Figure 2. (a) A schema of methylation specific PCR. U-primer and M-primer was desigend for each sequence. U, Unmethylated; M, Methylated; (b) A schema of quantitative methylation specific PCR. A fluorescent dye and a quencher labelled hybridization probe was desigend between the 2 primers. Fluorescent dye emits its fluorescence when the DNA polymerase cleaved the fluorescent dye from the probe. F, Fluorescent dye; Q, Quencher; Poly, DNA Polymerase.

\subsection{Quantitative Methylation Specific PCR ( $q M S P$ )}

In the recent studies we reviewed, most of the studies used qMSP as a method of methylation analysis; thus, this method could be called the "gold standard". Among the quantitative methods, MethyLight, which uses a TaqMan hybridization probe in addition to conventional MSP, is the most common qMSP technique [25]. With the MethyLight technology, sequence discrimination can be done by designing the primers and probe (which can be referred to as Southern hybridization-containing PCR, to further increase its specificity compared to conventional PCR) to contain $\mathrm{CpG}$ sites of interest (Figure $2 \mathrm{~b}$ ). The M-primer and U-primer are used as forward and reverse primers, respectively; M-probes (probes designed to recognize methylated CpGs) and U-probes (probes designed to recognize unmethylated $\mathrm{CpGs}$ ) are then designed. Theoretically, the combination of these primers and probes will design eight sequence variants $(2 \times 2 \times 2)$ within one sequence. Significant methylation information can be obtained by analyzing, both, fully methylated and fully unmethylated sequences. Quantification of methylation status is calculated from the ratio between the values of these two 
sequences (fully methylated and unmethylated). Most of the studies reviewed that performed qMSP used a combination of fully methylated sequences (M-primer and M-probe). Quantification can also be done by calculating the ratio between methylated sequences and reference genes ( $\beta$-actin etc.). With this technique, MSP becomes more specific and no more electrophoresis is required. Furthermore, with the quantitative analysis of methylation status using qMSP, we can select any sensitivity desired in cancer screening.

\subsection{Methyl BEAMing}

Diel et al. [8] reported on a sensitive assay, called BEAMing, for the detection of mutated ctDNA. The name "BEAMing" was derived from its principal components: Beads, emulsion, amplification, and magnetics (Figure 3). Methyl BEAMing is a modified technique of BEAMing, used for methylation analyses. The PCR primers are designed to amplify methylated and unmethylated templates. PCR amplification of individual DNA molecules takes place within aqueous nanocompartments, suspended in a continuous oil phase. Each aqueous nanocompartment contains the DNA polymerase, template DNA, primers, and beads. When the PCR reaction occurs in each of the compartments, the PCR product binds to the bead so that each bead ends up with thousands of PCR products. After PCR, the beads are collected by breaking the emulsion and the fluorescent probe, which hybridizes specifically to either methylated- or unmethylated-derived sequences on the beads. Li et al. [26] used cyanine dye 5 (Cy5)-labeled probes for methylated sequences, and fluorescein isothiocyanate (FITC)-labeled probes for unmethylated sequences. Beads are analyzed with a flow cytometer.

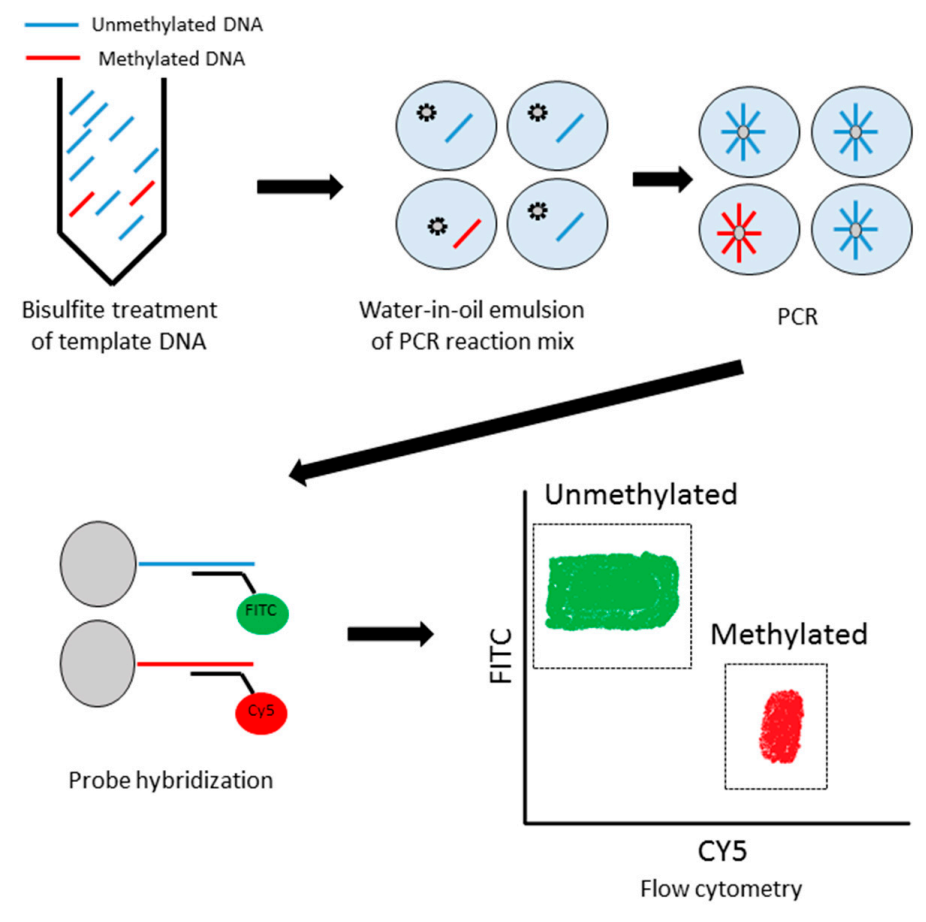

Figure 3. A schema of Methyl-BEAMing. Template DNA were amplified in water-in-oil emulsion by digital PCR. Methylation status was analyzed by a flow cytometer after methylation-specific probe hybridization.

\section{Use of Bodily Fluids for Cancer Detection}

\subsection{Saliva}

Methylation status of salivary DNA is performed for early detection of head and neck squamous cell carcinoma (HNSCC). Several genes have been analyzed for their promoter hypermethylation. 
Among the genes, EDNRB was the most focused gene for its diagnostic power; however, the specificity was lower than expected.

Saliva is a bodily fluid that can be easily and non-invasively obtained without difficult processes. Saliva has been used for early detection of HNSCCs (Table 1 and Table S1) [27-34]. All reports we reviewed used salivary DNA obtained from a salivary wash (an amount from 10 to $25 \mathrm{~mL}$ ). A study of the detection of HNSCC using salivary DNA methylation was first reported by Rosas et al. [27] in 2001. Saliva was collected from 30 HNSCC patients and another 30 healthy controls. The methylation status of $p 16, M G M T$, and DAPK genes were analyzed using MSP. At least one gene was hypermethylated in $56.0 \%$ of the tumor tissues and $36.6 \%$ of the saliva of HNSCC patients. In sixty-five percent of the patients whose tumor tissues were hypermethylated, hypermethylation could be successfully detected in their salivary DNA. In contrast, only one case was hypermethylated in healthy controls. As a result, the sensitivity and specificity of the study was $36.6 \%$ and $96.6 \%$, respectively. Righini et al. [28] performed similar analyses, but added another three genes (TIMP3, CDH1, RASSF1A). The sensitivity and specificity of the study were $78 \%$ and $100 \%$, respectively. Adding the candidate genes of hypermethylation, they could improve the sensitivity of the study. Carvalho et al. [34] analyzed several gene panels of which the sensitivity and specificity were $22-35 \%$ and $90-97 \%$, respectively, by the combination of 13 genes. The association with hypermethylation of EDNRB in saliva and HNSCC was analyzed in several studies [29,30,33]. Demokan et al. [30] analyzed hypermethylation of the EDNRB gene in HNSCC tissues and saliva. Tumor-specific hypermethylation of EDNRB was reported in the study, and the saliva from patients with HNSCC showed frequent hypermethylation. EDNRB hypermethylation of saliva was used for the detection of HNSCC with a sensitivity of $67.6 \%$ and a specificity of $93.2 \%$. Comparing the other genes reported, EDNRB shows a higher sensitivity and specificity for detecting HNSCC. However, the prospective study was conducted by the same group, and the specificity was lower than expected (51\%).

\subsection{Sputum}

The methylation status of sputum was analyzed for the detection of lung cancer. Hypermethylation of RASSF1A has been analyzed, from early studies to recent studies. Most of the studies containing the RASSF1A gene among the analyzed genes resulted in good sensitivity and specificity; thus, hypermethylation of the RASSF1A gene might be a promising biomarker for lung cancer detection.

Sputum is broadly used for the detection of lung cancer. Lung cancer is the leading cause of cancer deaths in the world. According to the National Comprehensive Cancer Network (NCCN) guidelines, the first method used for the screening of lung cancer for high risk cohorts is a baseline low-dose computed tomography (CT) [35]. Classically, cytology of sputum has been performed for the purpose of lung cancer diagnosis. The use of sputum is noninvasive and inexpensive compared to a CT scan; however, the sensitivity and specificity of the diagnosis of lung cancer is reported to be $66 \%$ and $99 \%$ [36], respectively.

In the past few decades, molecular approaches to detect lung cancer, using sputum, have been reported (Table 2 and Table S2) [37-50]. Honorio et al. [38] analyzed promoter hypermethylation of the RASSF1A gene in sputum in 2003. The sensitivity was 50\% (4/8) for small cell lung cancer (SCLC) and $21 \%(5 / 24)$ for non-small cell lung cancer (NSCLC). Belinsky et al. [43] analyzed hypermethylation of the $p 16, M G M T, R A S S F 1 A, D A P K, H C A D, P A X 5 \alpha, P A X 5 \beta$, and GATA5 genes in sputum and serum using MSP. In their study, they showed that the sensitivity of sputum for the detection of lung cancer was higher than that of serum. The positive predictive value increased to $86 \%$ with a panel of the top four genes ( $p 16, D A P K, P A X 5 \beta$, and GATA5) in sputum. Shivapurkar et al. [42] also showed that a combination of several genes could increase the sensitivity. They analyzed four genes (3-OST-2, RASSF1A, p16, and APC) according to hypermethylation in sputum. The sensitivity to detecting lung cancer in each gene was $31 \%, 38 \%, 23 \%$, and $23 \%$, respectively; however, the sensitivity increased to $54 \%$ and $62 \%$ with a specificity of $100 \%$ by the combination of $3-O S T-2$ and RASSF1A or all of four genes. In recent years, Hubers et al. [47] have produced several reports regarding sputum 
hypermethylation for lung cancer diagnosis; their first report was published in 2014 [48]. In 2014, they analyzed the hypermethylation of three genes (RASSF1A, APC, and cytoglobin) in relatively large cohorts. Among three genes, RASSF1A showed the best results to discriminate lung cancer cases from control cases. Its sensitivity and specificity, in both sets, were $41-52 \%$ and $94-96 \%$, respectively. Considering that these results were derived from just one gene, RASSF1A might have great potential as a diagnostic biomarker. Furthermore, Hubers et al. [49] validated their results in an independent set with the addition of some genes. In that study, RASSF1A, APC, cytoglobin, 3OST2, PRDM14, FA19A4, and PHACTR3 were analyzed using qMSP. The RASSF1A gene, again, showed the best results of sensitivity and specificity among the seven genes (sensitivity of $26.5-42.5 \%$, specificity of 88.3\%-96.5\%). In the most recent reports by Hulbert et al. [50] another set of six genes (SOX17, TAC1, HOXA7, CDO1, HOA9, and ZFP42) was analyzed by using a new extraction method for DNA called methylation-on-beads (MOB), as they thought that a reduction of sensitivity to methylation detection might occur due to technical limitations. Results of the study were surprising, with a sensitivity and specificity in the genes that showed the best results: $86 \%$ and $75 \%$ (TAC1), 63\% and 92\% (HOXA7), and $84 \%$ and $88 \%$ (SOX17). The results of these three genes were comparable to that of RASSF1A.

\subsection{Stool}

Methylation analysis in CRC detection has been developed, and the fecal occult blood test demonstrates excellent performance in CRC screening. The fecal DNA test was improved and its ability to be used for cancer screening was compared to the fecal immunochemical test (FIT) in a large cohort; its sensitivity was superior to that of FIT.

Stool has already been widely used for CRC detection in the fecal occult blood test (FOBT). FOBT can be divided into two types: Guaiac FOBT and FIT. Guaiac FOBT has been used for CRC screening since the 1970s, and its usability for reduction in CRC mortality has been proven by several studies [51-53]. The sensitivity and specificity of the test is reported to be $31-63 \%$ and $92-96 \%[54,55]$, respectively. Guaiac FOBT (gFOBT), however, does not positively react specifically to human blood, and so dietary restrictions are necessary for this test. Moreover, gFOBT requires three independent stool samples. On the other hand, FIT detects human hemoglobin using immunological assays. It does not require dietary restrictions and needs a single sample of stool. The sensitivity and specificity of FIT were reported in a recent meta-analysis to be $79 \%$ and $94 \%$ [56], respectively. Compared to gFOBT, FIT has been performed in several studies, all of which concluded that FIT has a higher sensitivity in detecting colorectal neoplasia $[55,57,58]$.

On the other hand, several of studies reported fecal DNA methylation for the early detection of CRC or adenoma (Table 3 and Table S3) [54,59-74]. In 2004, Müller et al. [59] analyzed the hypermethylation of several genes and concluded that hypermethylation of the SFRP2 gene in stool samples can detect CRC with a sensitivity and specificity of $77-90 \%$ and $77 \%$, respectively. While the SFRP2 gene showed excellent sensitivity to detect CRC, its specificity was poor. Lenhard et al. [61] reported that hypermethylation of the HIC1 gene in stool samples can detect CRC with a sensitivity of $42 \%$ and a specificity of $100 \%$. Similarly, Chen et al. [62] reported that hypermethylation of the vimentin gene could detect CRC with a sensitivity of $46 \%$ and a specificity of $90 \%$. Moreover, hypermethylation of vimentin could detect Stage I and II CRC with a sensitivity of $43 \%$. According to these results, analysis of the hypermethylation of single genes potentially has limitations with regard to sensitivity or specificity. From this point of view, Huang et al. [63] analyzed the hypermethylation of the SFRP2, HPP1, and MGMT genes in stool DNA from a large population (52 CRC, 35 benign colorectal disease, and 24 healthy controls). The sensitivity and specificity to detect CRC in the three combined genes was $96.2 \%$ and $95.8 \%$, respectively. Among the three genes, SFRP 2 showed the best sensitivity and specificity ( $94.2 \%$ and $95.8 \%$, respectively). 
Table 1. Studies of methylation analysis of saliva for the detection of head and neck squamous cell carcinoma.

\begin{tabular}{|c|c|c|c|c|c|c|c|}
\hline Author & Year & Method & Prospective Study & $\begin{array}{c}\text { Sample Size } \\
\text { (Number of Patients) }\end{array}$ & Gene & Sensitivity (\%) & Specificity (\%) \\
\hline Rosas et al. [27] & 2001 & MSP & No & $\begin{array}{c}\text { HNSCC (30) } \\
\text { Healthy control (30) }\end{array}$ & $D A P K, M G M T, p 16$ & At least 1 gene $(37 \%)$ & At least 1 gene $(97 \%)$ \\
\hline Righini et al. [28] & 2007 & MSP & No & $\begin{array}{c}\text { HNSCC (60) } \\
\text { Non Malignant (30) }\end{array}$ & $\begin{array}{l}\text { CDH1, DAPK, MGMT, } \\
\text { p16, RASSF1, TIMP3 }\end{array}$ & At least 1 gene $(79 \%)$ & At least 1 gene $(100 \%)$ \\
\hline Carvalho et al. [34] & 2008 & qMSP & No & $\begin{array}{l}\text { HNSCC (211) } \\
\text { Control (527) }\end{array}$ & $\begin{array}{c}\text { AIM1, CCNA1, CCND2, CDH1, } \\
\text { DAPK, DCC, ESR1, MGMT, MINT1, } \\
\text { MINT31, PGP9.5, p16, TIMP3 }\end{array}$ & At least 1 of 4 gene (31\%) & At least 1 of 4 gene $(90 \%)$ \\
\hline Demokan et al. [29] & 2010 & qMSP & No & $\begin{array}{c}\text { HNSCC (71) } \\
\text { Healthy Control (61) }\end{array}$ & EDNRB, KIF1A & $E D R N B+\operatorname{KIF} 1 A(77 \%)$ & EDRNB + KIF1A (93\%) \\
\hline Pattani et al. [30] & 2010 & qMSP & Yes & $\begin{array}{c}\text { Clinically high risk patients } \\
\text { Total (191) } \\
\text { Malignant (35) } \\
\text { Premalignant (43) } \\
\text { Benign (113) }\end{array}$ & EDNRB & $\operatorname{EDNRB}(65 \%)$ & EDNRB (51\%) \\
\hline Carvalho et al. [31] & 2011 & qMSP & No & HNSCC (61) & $\begin{array}{l}\text { CCNA1, DAPK, DCC, MGMT, } \\
\text { MINT31, p16, TIMP3 }\end{array}$ & At least 1 gene $(54 \%)$ & \\
\hline Schussel et al. [33] & 2013 & qMSP & Yes & $\begin{array}{l}\text { Clinically high risk patients } \\
\text { HNSCC or dysplasia (48) } \\
\text { Benign (113) }\end{array}$ & $D C C, E D N R B$ & $\begin{array}{c}E D R N B+D C C+\text { risk } \\
\text { classification }(75 \%)\end{array}$ & $\begin{array}{c}E D R N B+D C C+\text { risk } \\
\text { classification }(48 \%)\end{array}$ \\
\hline Rettori et al. [32] & 2013 & qMSP & No & $\begin{array}{c}\text { HNSCC (146) } \\
\text { Healthy control (60) }\end{array}$ & $\begin{array}{c}C C N A 1, D A P K, D C C, M G M T, T I M P 3, \\
\text { and other } 19 \text { genes }\end{array}$ & At least 1 gene $(55 \%)$ & At least 1 gene $(76 \%)$ \\
\hline
\end{tabular}

Table 2. Studies of methylation analysis of the sputum for the detection of lung cancer.

\begin{tabular}{|c|c|c|c|c|c|c|c|}
\hline Author & Year & Method & Prospective Study & $\begin{array}{c}\text { Sample Size } \\
\text { (Number of Patients) }\end{array}$ & Gene & Sensitivity (\%) & Specificity (\%) \\
\hline Belinsky et al. [37] & 1998 & MSP & No & $\begin{array}{c}\text { LC }(7) \\
\text { Smokers (26) } \\
\end{array}$ & $p 16$ & $p 16(43 \%)$ & $p 16(81 \%)$ \\
\hline Honorio et al. [38] & 2003 & MSP & No & $\begin{array}{c}\text { SCLC (8) } \\
\text { NSCLC (24) } \\
\text { Chronic Smokers (13) }\end{array}$ & RASSF1A & $\begin{array}{l}\text { SCLC; RASSF1A }(50 \%) \\
\text { NSCLC; RASSF1A }(21 \%) \\
\text { Chronic Smokers; } \\
\text { RASSF1A }(31 \%) \\
\end{array}$ & \\
\hline Konno et al. [39] & 2004 & MSP & No & $\begin{array}{c}\text { LC (78) } \\
\text { None LC (52) }\end{array}$ & $A P C, p 16, R A R \beta$ & $\begin{array}{c}A P C(28 \%), p 16(22 \%) \\
\operatorname{RAR\beta }(27 \%)\end{array}$ & $\begin{array}{c}A P C(96 \%), p 16(100 \%), \\
\operatorname{RAR\beta }(93 \%)\end{array}$ \\
\hline Belinsky et al. [41] & 2006 & $\begin{array}{l}\text { Nested } \\
\text { MSP }\end{array}$ & No & $\begin{array}{c}\text { LC (98) } \\
\text { Healthy Controls (92) }\end{array}$ & $\begin{array}{c}\text { BETA3, DAPK, GATA4, GATA5, } \\
\text { HCAD, HLHP, IGFBP3, LAMC2, } \\
\text { MGMT, PAX5 }, \text { PAX5 } \beta, p 16, \\
\text { RASSF1A, SFRP1 }\end{array}$ & $\begin{array}{c}\text { GATA5 }(74 \%), \text { LAMC2 } \\
(72 \%), \text { SFRP1 }(68 \%)\end{array}$ & $\begin{array}{c}\text { GATA5 }(74 \%), \text { LAMC2 } \\
(30 \%), \text { SFRP1 }(29 \%)\end{array}$ \\
\hline
\end{tabular}


Table 2. Cont

\begin{tabular}{|c|c|c|c|c|c|c|c|}
\hline Author & Year & Method & Prospective Study & $\begin{array}{c}\text { Sample Size } \\
\text { (Number of Patients) }\end{array}$ & Gene & Sensitivity (\%) & Specificity (\%) \\
\hline Cirincione et al. [40] & 2006 & MSP & No & $\begin{array}{c}\text { LC (18) } \\
\text { Healthy Controls } \\
\text { (smoker) (112) }\end{array}$ & $p 16, R A R \beta 2$, RASSF1A & At least 1 gene $(50 \%)$ & At least 1 gene $(38 \%)$ \\
\hline Belinsky et al. [43] & 2007 & MSP & No & LC (Stage III) (72) & $\begin{array}{l}\text { DAPK, GATA5, HCAD, MGMT, } \\
\text { PAX5 } \alpha, \text { PAX } 5 \beta, p 16, \text { RASSF1A }\end{array}$ & $\begin{array}{c}\text { GATA5 }(43 \%), M G M T(32 \%), \\
p 16(40 \%)\end{array}$ & \\
\hline Shivapurkar et al. [42] & 2007 & qMSP & No & $\begin{array}{c}\text { NSCLC (13) } \\
\text { Controls without LC (25) }\end{array}$ & $A P C, p 16, R A S S F 1 A, H S 3 S T 2$ & At least 1 gene $(62 \%)$ & At least 1 gene $(100 \%)$ \\
\hline Shivapurkar et al. [44] & 2008 & qMSP & No & $\begin{array}{c}\text { LC (13) } \\
\text { Non Cancer (25) } \\
\end{array}$ & $C Y G B$ & CYGB $(30 \%)$ & CYGB $(100 \%)$ \\
\hline Guzmán et al. [45] & 2012 & MSP & No & $\begin{array}{c}\text { LC (26) } \\
\text { COPD (23) } \\
\text { Healthy Controls (33) }\end{array}$ & $C D H 1, M G M T, p 16$ & $\begin{array}{c}\text { LC } \\
\text { CDH1 (35\%), MGMT (65\%), } \\
\text { p16 (73\%) } \\
\text { COPD } \\
\text { CDH1 (45\%), MGMT (65\%), } \\
\text { p16 (70\%) } \\
\text { Healthy controls } \\
\text { CDH1 (32\%), MGMT }(6 \%), \\
\text { p16 (9\%) } \\
\end{array}$ & \\
\hline Leng et al. [46] & 2012 & $\begin{array}{l}\text { Nested } \\
\text { MSP } \\
\text { (cohort1) } \\
\text { qMSP } \\
\text { (cohort2) }\end{array}$ & No & $\begin{array}{c}\text { Cohort } 1 \\
\text { LC (64) } \\
\text { Non Cancer (64) } \\
\text { Cohort } 2 \\
\text { LC (40) } \\
\text { Non Cancer (90) } \\
\end{array}$ & GATA5, PAX5 & $\begin{array}{c}\text { Cohort } 1 \\
\text { GATA5 }(33 \%), \text { PAX5 } \alpha(25 \%), \\
\text { SULF2 }(34 \%) \\
\text { Cohort } 2 \\
\text { GATA5 }(78 \%), \text { PAX5 } \alpha(63 \%), \\
\text { SULF2 }(78 \%) \\
\end{array}$ & $\begin{array}{c}\text { Cohort } 1 \\
\text { GATA5 (74\%), PAX5 } \alpha \\
(80 \%), \text { SULF2 (75\%) } \\
\text { Cohort } 2 \\
\text { GATA5 (53\%), PAX5 } \alpha \\
(67 \%), \text { SULF2 }(45 \%) \\
\end{array}$ \\
\hline Hubers et al. [48] & 2014 & qMSP & No & $\begin{array}{c}\text { LC (20) } \\
\text { COPD (31) }\end{array}$ & $\begin{array}{l}\text { APC, CYGB, FAM19A4, HS3ST2, } \\
\text { PHACTR3, PRDM14, RASSF1A }\end{array}$ & RASSF1A + $3 O S T 2(85 \%)$ & RASSF1A + 3 OST2 (74\%) \\
\hline Hubers et al. [47] & 2014 & qMSP & No & $\begin{array}{c}\text { Set1 } \\
\text { LC (98) } \\
\text { None LC (90) } \\
\text { Set2 } \\
\text { LC (60) } \\
\text { none LC (445) } \\
\end{array}$ & $A P C, C Y G B, R A S S F 1 A$ & $\begin{array}{l}\text { Set1; At least } 1 \text { gene }(63 \%) \\
\text { Set2; At least } 1 \text { gene }(90 \%)\end{array}$ & $\begin{array}{l}\text { Set1; At least } 1 \text { gene }(78 \%) \\
\text { Set2; At least } 1 \text { gene }(47 \%)\end{array}$ \\
\hline Hubers et al. [49] & 2015 & qMSP & No & $\begin{array}{c}\text { Learning set } \\
\text { LC (73) } \\
\text { none LC (86) } \\
\text { Validation set } \\
\text { LC (159) } \\
\text { none LC (154) } \\
\end{array}$ & $\begin{array}{l}\text { APC, CYGB, FA19A4, HS3ST2, } \\
\text { PHACTR3, PRDM14, RASSF1A }\end{array}$ & $\begin{array}{c}\text { Learning Set } \\
\text { HS3ST2 + PHACTR3 + } \\
\text { RASSF1A (82\%) } \\
\text { Validation Set } \\
\text { HS3ST2 + PHACTR3 + } \\
\text { RASSF1A (79\%) } \\
\end{array}$ & $\begin{array}{c}\text { Learning Set } \\
\text { HS3ST2 + PHACTR3 + } \\
\text { RASSF1A (66\%) } \\
\text { Validation Set } \\
\text { HS3ST2 + PHACTR3 + } \\
\text { RASSF1A }(64 \%) \\
\end{array}$ \\
\hline Hulbert et al. [50] & 2016 & qMSP & No & $\begin{array}{c}\text { LC (90) } \\
\text { none LC (24) }\end{array}$ & $\begin{array}{c}\text { CDO1, HOXA7, HOXA9, SOX17, } \\
\text { TAC1, ZFP42 }\end{array}$ & $\begin{array}{l}\text { HOXA7 + SOX17 + } \\
\text { TAC1 }(98 \%)\end{array}$ & $\begin{array}{l}\text { HOXA7 + SOX17 + } \\
\text { TAC1 (71\%) }\end{array}$ \\
\hline
\end{tabular}

LC: Lung Cancer; COPD: Chronic Obstructive Pulmonary Disease. 
Table 3. Studies of methylation analysis of the stool for the detection of colorectal cancer.

\begin{tabular}{|c|c|c|c|c|c|c|c|}
\hline Author & Year & Method & Prospective Study & $\begin{array}{c}\text { Sample Size } \\
\text { (Number of Patients) }\end{array}$ & Gene & Sensitivity (\%) & Specificity (\%) \\
\hline Song et al. [60] & 2004 & MSP & No & $\begin{array}{c}\text { CRC (20) } \\
\text { Normal CF (20) }\end{array}$ & APC, ATM, HLTF, MGMT, hMLH-1 & At least 1 gene $(70 \%)$ & \\
\hline Müller et al. [59] & 2004 & qMSP & No & $\begin{array}{c}\text { Training Set } \\
\text { CRC (10) } \\
\text { Healthy Control (13) } \\
\text { Validation Set } \\
\text { CRC (13) } \\
\text { Healthy Control (13) }\end{array}$ & SFRP2 & $\begin{array}{l}\text { Training Set; SFRP2 }(90 \%) \\
\text { Validation Set; SFRP2 (77\%) }\end{array}$ & $\begin{array}{l}\text { Training Set; SFRP2 (77\%) } \\
\text { Validation Set; SFRP2 (77\%) }\end{array}$ \\
\hline Lenhard et al. [61] & 2005 & MSP & No & $\begin{array}{c}\text { CRC (26) } \\
\text { Adenoma (13) } \\
\text { Hyperplastic Polyp (9) } \\
\text { CIBD (9) } \\
\text { Normal control (32) }\end{array}$ & HIC1 & $\begin{array}{c}\text { CRC; } \operatorname{HIC1}(42 \%) \\
\text { Adenoma; HIC1 (31\%) }\end{array}$ & CRC + Adenoma; HIC1 (98\%) \\
\hline Chen et al. [62] & 2005 & MSP & No & $\begin{array}{c}\text { CRC (94) } \\
\text { Normal Control (198) }\end{array}$ & VIM & $\begin{array}{c}\text { All Stages; VIM (46\%) } \\
\text { Stage I and II; VIM (43\%) }\end{array}$ & $\operatorname{VIM}(90 \%)$ \\
\hline Huang et al. [63] & 2007 & MSP & No & $\begin{array}{c}\text { CRC (52) } \\
\text { Adenoma (21) } \\
\text { Hyperplastic Polyp (8) } \\
\text { Ulcerative Colitis (6) } \\
\text { Healthy Control (24) }\end{array}$ & $H P P 1, M G M T, S F R P 2$ & $\begin{array}{l}\text { CRC; At least } 1 \text { gene }(96 \%) \\
\text { Adenoma; At least } 1 \text { gene }(71 \%)\end{array}$ & CRC + Adenoma; At least 1 gene $(96 \%)$ \\
\hline Zhang et al. [64] & 2007 & MSP & No & $\begin{array}{c}\text { CRC (29) } \\
\text { Adenoma (7) } \\
\text { Healthy Control (17) }\end{array}$ & SFRP1 & CRC + Adenoma; SFRP1 (89\%) & CRC + Adenoma; SFRP1 (86\%) \\
\hline Wang et al. [65] & 2008 & qMSP & No & $\begin{array}{c}\text { CRC (69) } \\
\text { Adenoma (34) } \\
\text { Hyperplastic Polyp (26) } \\
\text { Healthy Control (30) }\end{array}$ & SFRP2 & $\begin{array}{c}\text { CRC; SFRP2 (87\%) } \\
\text { Adenoma; SFRP2 (62\%) } \\
\text { Hyperplastic Polyp; SFRP2 (42\%) }\end{array}$ & CRC + Adenoma; SFRP2 (93\%) \\
\hline Ahlquist et al. [54] & 2008 & $\begin{array}{l}\text { OBT } \\
\text { SDT }\end{array}$ & Yes & $\begin{array}{c}\text { Total (3764) } \\
\text { CRC (39) } \\
\text { Adenoma (251) }\end{array}$ & $\begin{array}{l}\text { SDT-1 } \\
\text { SDT-2 }\end{array}$ & $\begin{array}{c}\text { CRC + Adenoma } \\
\text { Hemoccult }(11 \%), \\
\text { HemoccultSensa }(21 \%), \text { SDT-1 } \\
(20 \%), \text { SDT-2 }(40 \%)\end{array}$ & $\begin{array}{l}\text { CRC + Adenoma; Hemoccult }(98 \%) \\
\text { HemoccultSensa }(97 \%) \text {, SDT-1 }(96 \%)\end{array}$ \\
\hline Nagasaka et al. [69] & 2009 & Hi-SA & No & $\begin{array}{c}\text { CRC (84) } \\
\text { Adenoma (56) } \\
\text { Hyperplastic Polyp (12) } \\
\text { Without Neoplasms (113) } \\
\text { Other Disease (31) }\end{array}$ & RASSF2, SFRP2 & $\begin{array}{c}\text { CRC } \\
\text { RASSF2 (27\%), SFRP2 (31\%) } \\
\text { Adenoma } \\
\text { RASSF2 }(11 \%), \text { SFRP2 }(25 \%)\end{array}$ & CRC + Adenoma; RASSF2 (95\%), SFRP2 (92\%) \\
\hline
\end{tabular}


Table 3. Cont

\begin{tabular}{|c|c|c|c|c|c|c|c|}
\hline Author & Year & Method & Prospective Study & $\begin{array}{c}\text { Sample Size } \\
\text { (Number of Patients) }\end{array}$ & Gene & Sensitivity (\%) & Specificity (\%) \\
\hline Glöckner et al. [68] & 2009 & MSP & No & $\begin{array}{c}\text { CRC (84) } \\
\text { Adenoma (26) } \\
\text { CF negative control (87) }\end{array}$ & TFPI2 & $\begin{array}{c}\text { Training Set } \\
\text { CRC; TFPI2 (89\%) } \\
\text { Validation Set } \\
\text { CRC; TFPI2 (76\%) } \\
\text { Adenoma; TFPI2 (21\%) }\end{array}$ & $\begin{array}{c}\text { Training Set } \\
\text { CRC; TFPI2 (79\%) } \\
\text { Validation Set } \\
\text { CRC; TFPI2 (93\%) } \\
\text { Adenoma; TFPI2 (93\%) }\end{array}$ \\
\hline Hellebrekers et al. [70] & 2009 & qMSP & No & $\begin{array}{c}\text { Set1 } \\
\text { CRC (28) } \\
\text { Healthy Control (45) } \\
\text { Set2 } \\
\text { CRC (47) } \\
\text { Healthy Controls (30) }\end{array}$ & $\begin{array}{l}\text { GATA4 } \\
\text { GATA5 }\end{array}$ & $\begin{array}{l}\text { Set1; GATA4 (71\%) } \\
\text { Set2; GATA4 (51\%) }\end{array}$ & $\begin{array}{l}\text { Set1; GATA4 }(84 \%) \\
\text { Set2; GATA4 (93\%) }\end{array}$ \\
\hline Melotte et al. [71] & 2009 & qMSP & No & $\begin{array}{c}\text { Training Set } \\
\text { CRC (28) } \\
\text { CF Negative Control (45) } \\
\text { Validation Set } \\
\text { CRC (47) } \\
\text { CF Negative Control (30) }\end{array}$ & NDRG4 & $\begin{array}{l}\text { Training Set; NDRG4 (61\%) } \\
\text { Validation Set; NDRG4 (53\%) }\end{array}$ & $\begin{array}{c}\text { Training Set; NDRG4 }(93 \%) \\
\text { Validation Set; NDRG4 (100\%) }\end{array}$ \\
\hline Baek et al. [66] & 2009 & MSP & No & $\begin{array}{c}\text { CRC (60) } \\
\text { Adenoma (52) } \\
\text { CF Negative (37) }\end{array}$ & $M G M T, h M L H 1, V I M$ & $\begin{array}{c}\text { CRC; At least } 1 \text { gene }(75 \%) \\
\text { Adenoma; At least } 1 \text { gene }(60 \%)\end{array}$ & $\begin{array}{c}\text { CRC + Adenoma; } M G M T(86 \%), h M L H 1 \\
(100 \%), V I M(100 \%)\end{array}$ \\
\hline Kim et al. [67] & 2009 & qMSP & No & $\begin{array}{c}\text { CRC (20) } \\
\text { Adenoma (17) } \\
\text { CF Normal (15) }\end{array}$ & B4GALT, OSMR, SFRP1 & $\begin{array}{c}\text { CRC; OSMR + SFRP }(60 \%) \\
\text { Adenoma; OSMR + SFRP1 }(35 \%)\end{array}$ & CRC + Adenoma; OSMR + SFRP1 $(100 \%)$ \\
\hline Ahlquist et al. [72] & 2012 & SDT & No & $\begin{array}{c}\text { CRC (252) } \\
\text { Adenoma (133) } \\
\text { CF Negative Control (293) }\end{array}$ & $\begin{array}{c}\text { BMP3, NDRG4, TFPI2, VIM, kras } \\
\text { (mutation) }\end{array}$ & $\begin{array}{c}\text { CRC; SDT (85\%) } \\
\text { Adenoma (>1 cm); SDT (63\%) }\end{array}$ & $\begin{array}{c}\text { CRC; SDT ( } 89 \%) \\
\text { Adenoma }(>1 \mathrm{~cm}) ; \mathrm{SDT}(89 \%)\end{array}$ \\
\hline Imperiale et al. [73] & 2014 & SDT & Yes & $\begin{array}{l}\text { Total (9989) } \\
\text { CRC (65) }\end{array}$ & $B M P 3, N D R G 4$, kras (mutation) & SDT $(92 \%)$, FIT $(74 \%)$ & SDT $(90 \%)$, FIT $(96 \%)$ \\
\hline Zhang et al. [74] & 2014 & MSP & No & $\begin{array}{c}\text { CRC (48) } \\
\text { Adenoma (35) } \\
\text { Hyperplastic Polyp (32) } \\
\text { Healthy Control (30) }\end{array}$ & SFRP2, WIF-1 & $\begin{array}{c}\text { CRC; SFRP2 + WIF-1 (81\%) } \\
\text { Adenoma; SFRP2 + WIF-1 (81\%) }\end{array}$ & CRC + Adenoma; SFRP2 + WIF-1 (97\%) \\
\hline
\end{tabular}

CF: Colon Fiber; CIBD: Chronic Inflammatory Bowel Disease; Hi-SA: High-Sensitivity Assay for Bisulfite DNA; SDT-1: Stool DNA Test-1 (point mutations of kras, APC, and p53); SDT-2: Stool DNA Test-2 (kras mutation, APC mutator cluster regions, and methylation of VIM); OBT: Occult Blood Test. 
Fecal DNA tests have also been reported as a new screening test for CRC. Stool DNA test 1 (STD-1) and STD-2 are representative. STD-1 consists of a marker panel of 21 point mutations (three on Kras, 10 on $A P C$, and eight on $p 53$ ). STD-2 consists of three tumor-specific genetic change (Kras mutations, scanning of $A P C$ mutator cluster regions, and methylation of the vimentin gene). Ahlquist et al. [54] compared gFOBT, FIT, STD-1, and STD-2 for a screening test of colorectal neoplasm, and reported that, while STD-1 provided no improvement over FIT, STD-2 detected significantly more neoplasms than gFOBT and FIT. Ahlquist et al. [72] developed a next-generation stool DNA test and reported its performance. The test detects four methylated genes (vimentin, NDRG4, BMP3, and TFPI2) and mutation of the kras gene. Next generation stool tests can detect CRC and adenoma with sensitivities of $85 \%$ and $54 \%$, respectively. Moreover, the test had high detection rates for nonmetastatic stages of CRC ( $87 \%$ detection rate for Stage I-III CRCs). Furthermore, important advances in stool DNA tests, such as the use of stabilizing buffers and more discriminating markers, were incorporated. Imperiale et al. [73] reported a new stool DNA test in 2014, and the test (Cologuard ${ }^{\circledR}$ (Exact Science, Madison, WI, USA)) was approved as screening tools for CRC by the U.S. Food and Drug Administration (FDA). The sensitivity for detecting CRC was $92.3 \%$ with DNA testing, and $73.8 \%$ with FIT. Stool DNA tests could detect CRC significantly better than FIT $(p=0.002)$. Moreover, the DNA test could detect advanced precancerous regions (advanced adenomas or sessile serrated polyps measuring $>1 \mathrm{~cm}$ ) and polyps with high-grade dysplasia $(p<0.001$ and $p=0.004$, respectively). The specificity of the DNA test and FIT, however, were $86.6 \%$ and $94.9 \%$, respectively, and the number of patients who were excluded from the study was greater in the DNA tests group $(n=689)$ than in the FIT group $(n=34)$. As described above, cancer detection in stool has an advantage compared to other bodily fluids in the detection of cancer.

\subsection{Urine (For the Detection of Bladder Cancer)}

Studies of the analysis of urinary DNA methylation for the detection of bladder cancer have been performed broadly. Despite the numerous studies, none of the promising methylation markers have been found. Recently, urinary tests, combining methylation status and mutation status, were performed in large cohorts.

Urine has also been used to analyze its methylation status for the purpose of the early detection of urinary tract cancers. Classically, cytological examination of urine was performed; however, its sensitivity for low-grade and low-stage cancer was low. For that reason, alternative non-invasive tests have been developed. BTA stat ${ }^{\circledR}, \mathrm{BTA}$ TRAK ${ }^{\circledR}, \mathrm{NMP}-22^{\circledR}, \mathrm{UroVysion}^{\mathrm{TM}}$, and ImmunoCyt $/ \mathrm{uCyt}^{\mathrm{TM}}$ are FDA-approved test kits for bladder cancer detection. None of these, however, are used in daily clinical practice because of their low specificity and technical problems [75]. Several other molecular markers have been developed; however, none of the markers were confirmed as promising markers. In this section, studies on methylation analyses using urinary DNA for the detection of bladder cancer are reviewed (Table 4 and Table S4) [76-102].

The methylation status of urinary DNA for the detection of bladder cancer was first analyzed in 2002 by Chan et al. [76]. In this study, aberrant methylation in tumor samples was detected in RAR $\beta 2$ (87.8\%), DAPK (58.2\%), E-cadherin (63.3\%), and $p 16$ (26.5\%). Methylation was also analyzed in paired urine samples, of which sensitivities were $45.5 \%, 68.2 \%, 59.1 \%$, and $13.6 \%$, respectively. 
Table 4. Studies of methylation analysis of the urine for the detection of bladder cancer.

\begin{tabular}{|c|c|c|c|c|c|c|c|}
\hline Author & Year & Method & Prospective Study & $\begin{array}{c}\text { Sample Size } \\
\text { (Number of Patients) }\end{array}$ & Gene & Sensitivity (\%) & Specificity (\%) \\
\hline Chan et al. [76] & 2002 & MSP & No & $\begin{array}{c}\text { BC (22) } \\
\text { Normal Control (17) }\end{array}$ & DAPK, E-cadherin, $p 16, R A R \beta$ & At least 1 gene $(91 \%)$ & At least 1 gene $(77 \%)$ \\
\hline Chan et al. [77] & 2003 & MSP & No & $\begin{array}{c}\mathrm{BC}(14) \\
\text { Normal control (10) } \\
\end{array}$ & RASSF1A & RASSF1A (50\%) & RASSF1A (100\%) \\
\hline Sathyanarayana et al. [79] & 2004 & MSP & No & $\begin{array}{c}\text { BC (71) } \\
\text { Bladder Wash (28) } \\
\text { Voided Urine (43) } \\
\text { None Malignant (6) }\end{array}$ & LAMA3, LAMB3, LAMC2 & At least 1 gene $(49 \%)$ & At least 1 gene $(100 \%)$ \\
\hline Friedrich et al. [78] & 2004 & qMSP & No & $\begin{array}{c}\text { BC (37) } \\
\text { Normal Control (20) }\end{array}$ & BCL2, DAPK, TERT & $\begin{array}{c}\text { BCL2 (65\%), DAPK (22\%), } \\
\text { TERT (51\%) }\end{array}$ & At least 1 gene $(100 \%)$ \\
\hline Dulaimi et al. [80] & 2004 & MSP & No & $\begin{array}{c}\text { BC (45) } \\
\text { normal (12) } \\
\text { Inflammatory } \\
\text { Urinary Disease (9) }\end{array}$ & APC, p14, RASSF1A & At least 1 gene $(87 \%)$ & At least 1 gene $(100 \%)$ \\
\hline Hoque et al. [82] & 2006 & qMSP & No & $\begin{array}{c}\text { BC (175) } \\
\text { Normal Control (94) }\end{array}$ & ARF, GSTP1, MGMT, p16 & At least 1 gene $(69 \%)$ & At least 1 gene $(100 \%)$ \\
\hline Urakami S et al. [83] & 2006 & MSP & No & $\begin{array}{c}\text { BC (24) } \\
\text { Normal Control (20) }\end{array}$ & DKK3, SFRP1, SFRP2, SFRP4, SFRP5, WIF1 & At least 1 gene $(61 \%)$ & At least 1 gene $(93 \%)$ \\
\hline Yates et al. [81] & 2006 & qMSP & Yes & $\begin{array}{c}\text { BC (35) } \\
\text { Benign Control (35) } \\
\text { Healthy Volunteer (34) }\end{array}$ & $\begin{array}{c}\text { APC, DAPK, E-cadherin, GSTP1, } \\
p 14, p 16, \text { RARB, RASSF1A }\end{array}$ & $\begin{array}{c}\text { APC + E-cadherin + } \\
\text { RASSF1A }(69 \%)\end{array}$ & $\begin{array}{l}\text { APC + E-cadherin + } \\
\text { RASSF1A }(60 \%)\end{array}$ \\
\hline Yu et al. [84] & 2007 & MSP & No & $\begin{array}{c}\text { BC (132) } \\
\text { Normal Control (7) } \\
\text { Noncancerous Urinary } \\
\text { Lesion (23) } \\
\text { Other disease }(6) \\
\end{array}$ & $\begin{array}{c}\text { ABCC6, ALX4, BCL2, BMP3, BRCA1, CCNA1, } \\
\text { CDH13, CFTR, DRM, HPR1, ITGA4, MINT1, } \\
\text { MTA1, MYOD1, RASSF1A, RPRM, RUNX3, SALL3 }\end{array}$ & $\begin{array}{l}\text { Combination of } 11 \\
\text { genes }(92 \%)\end{array}$ & Combination of 11 genes $(87 \%)$ \\
\hline Sun et al. [85] & 2009 & MSP & No & $\begin{array}{c}\text { BC (82) } \\
\text { Noncancerous Urinary } \\
\text { Lesion (15) } \\
\text { Normal Control (5) }\end{array}$ & $\begin{array}{c}\text { CDH1, FANCF, LOXL1, LOXL4, p16, SFRP1, } \\
\text { SOX9, TIG1, TIMP3, XAF1 }\end{array}$ & $\begin{array}{c}\text { LOXL1 }(40 \%), \text { SFRP1 }(37 \%), \\
\text { XAF1 (71\%) }\end{array}$ & $\begin{array}{c}\text { LOXL1 }(73 \%), \text { SFRP1 }(93 \%), \\
\text { XAF1 (33\%) }\end{array}$ \\
\hline Lin et al. [87] & 2010 & MSP & No & $\begin{array}{c}\text { BC (57) } \\
\text { Normal Control (20) }\end{array}$ & E-cadherin, $p 14, p 16$, RASSF1A & At least 1 gene $(83 \%)$ & \\
\hline Renard et al. [86] & 2010 & qMSP & Yes & $\begin{array}{c}\text { Symptomatic patients } \\
\text { Training Set } \\
\text { BC (48) } \\
\text { Normal Control (121) } \\
\text { Validation Set } \\
\text { BC (35) } \\
\text { Normal Control (57) }\end{array}$ & NID2, TWIST1 & $\begin{array}{c}\text { Training Set; NID2 } \\
\text { and TWIST1 ( } 88 \%) \\
\text { Validation Set; NID2 } \\
\text { and TWIST1 }(94 \%)\end{array}$ & $\begin{array}{c}\text { Training Set; NID2 } \\
\text { and TWIST1 (94\%) } \\
\text { Validation Set; NID2 } \\
\text { and TWIST1 (91\%) }\end{array}$ \\
\hline
\end{tabular}


Table 4. Cont

\begin{tabular}{|c|c|c|c|c|c|c|c|}
\hline Author & Year & Method & Prospective Study & $\begin{array}{c}\text { Sample Size } \\
\text { (Number of Patients) } \\
\end{array}$ & Gene & Sensitivity (\%) & Specificity $(\%)$ \\
\hline Reinert et al. [89] & 2011 & MS-HRM & No & $\begin{array}{c}\text { BC (115) } \\
\text { BPH or Bladder Stone (59) }\end{array}$ & EOMES, HOXA9, POU4F2, ZNF154 & At least 3 genes $(84 \%)$ & At least 3 genes $(96 \%)$ \\
\hline Eissa et al. [88] & 2011 & MSP & No & $\begin{array}{c}\text { BC (210) } \\
\text { Benign Urological } \\
\text { Disease (61) } \\
\text { Normal Control (49) } \\
\end{array}$ & $A P C, R A R \beta 2$ & $A P C(60 \%), R A R \beta 2(63 \%)$ & $A P C(84 \%), R A R \beta 2(95 \%)$ \\
\hline Chen et al. [91] & 2011 & qMSP & No & $\begin{array}{c}\text { BC (30) } \\
\text { None Cancer Control (19) } \\
\end{array}$ & DAPK, IRF8, p14, RASSF1A, SFRP1 & $\begin{array}{l}\text { IRF8 }(57 \%), p 14(28 \%), \\
\text { SFRP1 (41\%) }\end{array}$ & $\begin{array}{l}\text { IRF8 }(95 \%), p 14(100 \%) \\
\text { SFRP1 }(100 \%)\end{array}$ \\
\hline Vinci et al. [90] & 2011 & qMSP & Yes & $\begin{array}{c}\text { Bladder cancer (108) } \\
\text { Control (105) } \\
\text { BPH (29) } \\
\text { Urinary tract infection (17) } \\
\text { Bladder Stone (16) } \\
\text { Normal Volunteer(43) } \\
\end{array}$ & $B C L 2, D A P K, h T E R T$ & At least 1 gene $(79 \%)$ & At least 1 gene $(90 \%)$ \\
\hline Serizawa et al. [92] & 2011 & qMSP & No & $\begin{array}{c}\text { BC (113) } \\
\text { Normal Control (33) }\end{array}$ & $\begin{array}{c}A P C, D B C 1, R A R B, R A S S F 1 A, \text { SFRP1, } \\
\text { SFRP2, SFRPA, SFRP5 } \\
\text { FGFR (mutation), PIK3CA (mutation), } \\
\text { RAS (mutation), TP53 (mutation) }\end{array}$ & Total $(70 \%)$ & Total $(94 \%)$ \\
\hline Chung et al. [94] & 2011 & qMSP & No & $\begin{array}{c}\text { BC (128) } \\
\text { None Cancer Control (110) }\end{array}$ & $\begin{array}{c}\text { A2BP1, CA10, DBC1, MYO3A, NKX6-2, } \\
\text { NPTX2, PENK, SOX11 }\end{array}$ & $\begin{array}{c}\text { CA10 + MYO3A + NKX6-2 + } \\
\text { SOX11 (81\%) }\end{array}$ & $\begin{array}{c}\text { CA10 + MYO3A + NKX6-2 + } \\
\text { SOX11 (97\%) }\end{array}$ \\
\hline Costa et al. [93] & 2011 & qMSP & No & $\begin{array}{c}\text { BC (50) } \\
\text { RCC (50) } \\
\text { PC (50) } \\
\text { Healthy Control (48) } \\
\end{array}$ & PCDH17, TCF 21 & $\begin{array}{c}\text { BC; PCDH17 + TCF21 }(60 \%) \\
\text { RCC; PCDH17 + TCF } 21(32 \%) \\
\text { PC; PCDH17 + TCF21 }(26 \%)\end{array}$ & $\begin{array}{c}\text { BC; PCDH17 + TCF21 (100\%) } \\
\text { RCC; PCDH17 + TCF21 (100\%) } \\
\text { PC; PCDH17 + TCF21 (100\%) }\end{array}$ \\
\hline Reinert et al. [95] & 2012 & qMSP & No & $\begin{array}{c}\text { BC (184) } \\
\text { BPH or Bladder Stone (35) }\end{array}$ & EOMES, HOXA9, POU4F2, TWIST1, VIM, ZNF154 & $\begin{array}{c}\text { EOMES (88\%), TWIST1 (88\%), } \\
\text { VIM }(89 \%)\end{array}$ & $\begin{array}{c}\text { EOMES }(97 \%), \text { TWIST1 }(100 \%), \\
\operatorname{VIM}(100 \%)\end{array}$ \\
\hline Chihara et al. [96] & 2013 & Pyrosequencing & No & $\begin{array}{c}\text { BC (73) } \\
\text { Healthy Volunteer (18) }\end{array}$ & $\begin{array}{c}\text { Hypermethylation; HOXA9_1, } \\
\text { HOXA9_2, MYOD, SOX1, TJP2 } \\
\text { Hypomethylation; CAPG, CASP8, } \\
\text { HLADPA1, IFNG, RIPK3, SPP1, VAMP8 }\end{array}$ & $\begin{array}{c}\text { HOXA9_1 }(86 \%), H O X A 9 \_2 \\
(86 \%), M Y O D(87 \%), \\
\text { TJP2 (93\%) }\end{array}$ & $\begin{array}{c}\text { HOXA9_1 (89\%), HOXA9_2 } \\
(62 \%), \text { MYOD }(88 \%), \text { TJP2 (56\%) }\end{array}$ \\
\hline
\end{tabular}


Table 4. Cont.

\begin{tabular}{|c|c|c|c|c|c|c|c|}
\hline Author & Year & Method & Prospective Study & $\begin{array}{c}\text { Sample Size } \\
\text { (Number of Patients) }\end{array}$ & Gene & Sensitivity (\%) & Specificity (\%) \\
\hline Abern et al. [98] & 2014 & qMSP & Yes & $\begin{array}{c}\text { Hematuria or on } \\
\text { surveillance for prior } \\
\text { NMIBC } \\
\text { Total (111) } \\
\text { BC (24) } \\
\text { None Cancer Control (87) }\end{array}$ & NID2, TWIST1 & NID2, TWIST1 (75\%) & NID2, TWIST1 (71\%) \\
\hline Hayashi et al. [97] & 2014 & qMSP & No & $\begin{array}{c}\text { BC (20) } \\
\text { Normal Control (20) } \\
\end{array}$ & $V G F$ & $V G F(40 \%)$ & $V G F(95 \%)$ \\
\hline Fantony et al. [100] & 2015 & qMSP & Yes & $\begin{array}{c}\text { Hematuria or on } \\
\text { surveillance for prior } \\
\text { NMIBC, or NMIBC treated } \\
\text { with BCG } \\
\text { Total (209) } \\
\text { BC (52) } \\
\text { Suspicious of BC (12) } \\
\text { Negative for Cystoscopy } \\
\text { (145) }\end{array}$ & NID2, TWIST1 & $\begin{array}{l}\text { Believe the positive }(67 \%) \\
\text { Believe the negative }(37 \%)\end{array}$ & $\begin{array}{l}\text { Believe the positive }(61 \%) \\
\text { Believe the negative }(86 \%)\end{array}$ \\
\hline Yeh et al. [99] & 2015 & qMSP & No & $\begin{array}{c}\text { Training set } \\
\text { BC (69) } \\
\text { None Cancer Control (28) } \\
\text { Test set } \\
\text { BC (33) } \\
\text { None Cancer Control (28) }\end{array}$ & ZNF671 & $\begin{array}{l}\text { Training Set; ZNF671 (42\%) } \\
\text { Test Set; ZNF671 (48\%) }\end{array}$ & $\begin{array}{l}\text { Training set; ZNF671 (93\%) } \\
\text { Test set; ZNF671 (89\%) }\end{array}$ \\
\hline Roperch et al. [101] & 2016 & qMSP & No & $\begin{array}{c}\text { BC (167) } \\
\text { None Cancer Control (105) }\end{array}$ & HS3ST2, SEPT9, SLIT2, FGFR3 (mutation) & $\begin{array}{c}\text { Total (Methylation + } \\
\text { Mutation) }(98 \%)\end{array}$ & $\begin{array}{l}\text { Total (Methylation + } \\
\text { Mutation) }(85 \%)\end{array}$ \\
\hline
\end{tabular}

BC: Bladder Cancer; RCC: Renal Cell Carcinoma; BPH: Benign Prostate Hyperplasia; NMIBC: Non Muscle Invasive Bladder Cancer; MS-HRM: Methylation Sensitive High Resolution Melting. 
Hoque et al. [82] analyzed the methylation of urinary DNA in a large cohort (175 for bladder cancer and 94 for age-matched control) using qMSP. They assessed p16, ARF, MGMT, and GSTP1; their sensitivities were $45 \%, 28 \%, 35 \%$, and $43 \%$, respectively; the specificity was $100 \%$. Despite their low sensitivity to individual genes for the detection of bladder cancer, combined sensitivity (at least one gene) was increased to $69 \%$. Yu et al. [84] also applied multiple gene panels for the detection of bladder cancer using urinary DNA methylation. They analyzed 18 genes, of which sensitivities were $12-58 \%$ and they searched for the optimal combination of the genes. A panel of 11 genes (SALL3, CFTR, ABCC6, HPP1, RASSF1A, MT1A, ALX4, CDH13, RPRM, MINT1, and BRCA1) had the highest sensitivity and a feasible specificity $(91.7 \%$ and $87.0 \%$, respectively). In this process, the sensitivity and specificity already reached $82.6 \%$ and $100 \%$ using a combination of four genes (SALL3, CFTR, ABCC6, and HPP1), and addition of another set of 11 genes increased the sensitivity to $91.7 \%$ in exchange for a decrease in specificity to $87.0 \%$.

In 2010, Renard et al. [86] identified two genes (TWIST1 and NID2) for the early detection of bladder cancer. In their study, they first performed a pharmacologic unmasking microarray to identify the candidate genes for the methylation marker and then they narrowed down the candidates by methylation analysis of bladder cancer tissue samples. Of the 10 genes they identified, they selected the TWIST1 and NID2 genes. The panel of two genes was applied to the detection of bladder cancer using urinary DNA methylation analyses. A higher sensitivity and feasible specificity were shown in both the training and validation sets (sensitivity; $88 \%$ and $94 \%$, specificity; $94 \%$ and $91 \%$, respectively), and, notably, a sensitivity of $80-89 \%$ was found for early-stage and low-grade cancer. This study, however, was later validated by two prospective studies that failed to replicate the excellent performance $[98,100]$. Recently, Dahmcke et al. [102] conducted a prospective study for the detection of bladder cancer in a patient cohort of gross hematuria. In this study, the methylation status of six genes (SALL3, ONECUT2, CCNA1, BCL2, EOMES, and VIM) and the mutation of two genes (TERT and FGFR3) were used as a test for urinary DNA. Patients with hematuria were concluded in the study $(n=475)$, and all of the patients underwent cystoscopy. Ninety-nine patients were diagnosed with bladder cancer. The sensitivity and specificity of the test were $97 \%$ and $77 \%$, respectively, and the area under the curve (AUC) of the test was calculated as $96.3 \%$. The negative predictive value was $99.0 \%$, and, with this value, the author noted that this DNA test could reduce the number of patients who would need to undergo cystoscopy.

\subsection{Urine (For the Detection of Prostate Cancer)}

Contrary to studies on the detection of bladder cancer, the number of urinary DNA methylation studies for prostate cancer is small; however, almost all studies analyzed the methylation status of GSTP1. Early studies suggested that GSTP1 methylation is a promising marker; however, a recent prospective study revealed it to have insufficient specificity.

The methylation status of urine has also been analyzed for the early detection of prostate cancer. The standard tools for early detection of prostate cancer are PSA and digital rectal exam (DRE). Due to its lower specificity in the discrimination of benign prostate hyperplasia (BPH), however, false positive results have been a clinical problem. Only $25 \%$ of men with PSA values between 4 and $10 \mathrm{ng} / \mathrm{mL}$ have a positive biopsy [103]. If the cut off value was set to $4.1 \mathrm{ng} / \mathrm{mL}$, the sensitivity and specificity were reported to be $20.5 \%$ and $93.8 \%$ [104], respectively. A new molecular biomarker is still required for the screening of prostate cancer. In this section, studies of methylation analyses of urinary DNA for the early detection of prostate cancer are reviewed (Table 5 and Table S5) [105-114]. 
Table 5. Studies of methylation analysis of the urine for the detection of prostate cancer.

\begin{tabular}{|c|c|c|c|c|c|c|c|}
\hline Author & Year & Method & Prospective Study & $\begin{array}{c}\text { Sample Size } \\
\text { (Number of Patients) }\end{array}$ & Gene & Sensitivity (\%) & Specificity (\%) \\
\hline Goessl et al. [105] & 2000 & MSP & No & $\begin{array}{c}\mathrm{PC}(33) \\
\mathrm{BPH}(26)\end{array}$ & GSTP1 & GSTP1 (36\%) & GSTP1 $(100 \%)$ \\
\hline Goessl et al. [108] & 2001 & MSP & No & $\begin{array}{c}\mathrm{PC}(29) \\
\mathrm{BPH}(40)\end{array}$ & GSTP1 & GSTP1 $(77 \%)$ & GSTP1 (97\%) \\
\hline Goessl et al. [107] & 2001 & MSP & No & $\begin{array}{c}\text { PC (40) } \\
\text { PIN (7) } \\
\text { BPH (45) }\end{array}$ & GSTP1 & $\begin{array}{l}\text { PC; GSTP1 (73\%) } \\
\text { PIN; GSTP1 (29\%) }\end{array}$ & PC and PIN; GSTP1 (98\%) \\
\hline Cairns et al. [106] & 2001 & MSP & No & PC (22) & GSTP1 & GSTP1 (27\%) & \\
\hline Jeronimo et al. [109] & 2002 & $\begin{array}{l}\text { MSP } \\
\text { qMSP }\end{array}$ & No & $\begin{array}{c}\mathrm{PC}(69) \\
\mathrm{BPH}(31)\end{array}$ & GSTP1 & $\begin{array}{l}\text { qMSP; GSTP1 }(19 \%) \\
\text { MSP; GSTP1 }(30 \%)\end{array}$ & qMSP and MSP; GSTP1 (67\%) \\
\hline Hoque et al. [110] & 2005 & qMSP & No & $\begin{array}{c}\text { PC (52) } \\
\text { None Cancer Control (91) }\end{array}$ & $\begin{array}{c}\text { APC, ARF, E-cadherin, GSTP1, MGMT, } \\
\text { p16, RAR } 32, \text { RASSF1A, TIMP3 }\end{array}$ & At least 1 of 4 genes $(87 \%)$ & At least 1 of 4 genes $(100 \%)$ \\
\hline Roupret et al. [111] & 2007 & qMSP & No & $\begin{array}{c}\text { PC (95) } \\
\text { None Cancer Control (38) }\end{array}$ & $\begin{array}{c}\text { APC, CDH1, DAPK, GSTP1, MGMT, p14, } \\
p 16, \text { RAR } \beta 2, \text { RASSF1A, TIMP3 }\end{array}$ & At least 1 of 4 genes $(89 \%)$ & At least 1 of 4 genes $(89 \%)$ \\
\hline Venar et al. [114] & 2008 & qMSP & Yes & $\begin{array}{c}\text { PSA > } 2.5 \mathrm{ng} / \mathrm{mL} \\
\text { Biopsy Positive (111) } \\
\text { Biopsy Negative (123) }\end{array}$ & $A P C, G S T P 1, R A R \beta 2$ & $\begin{array}{l}\text { Cohort1; At least } 1 \text { gene }(55 \%) \\
\text { Cohort2; At least } 1 \text { gene }(53 \%)\end{array}$ & $\begin{array}{l}\text { Cohort1; At least } 1 \text { gene }(80 \%) \\
\text { Cohort2; At least } 1 \text { gene }(76 \%)\end{array}$ \\
\hline Baden et al. [112] & 2009 & qMSP & Yes & $\begin{array}{c}\text { PSA } 2-10 \mathrm{ng} / \mathrm{mL} \\
\text { PC(178) } \\
\text { None Cancer Control (159) }\end{array}$ & $A P C, G S T P 1, R A R \beta 2$ & At least 1 Gene $(60 \%)$ & At least 1 Gene $(81 \%)$ \\
\hline Daniunaite et al. [113] & 2014 & qMSP & No & $\begin{array}{l}\mathrm{PC}(253) \\
\mathrm{BPH}(32)\end{array}$ & GSTP1, RARB, RASSF1 & $\begin{array}{c}\text { GSTP1 (11\%), RARB (29\%), } \\
\text { RASSF1 (45\%) }\end{array}$ & $\begin{array}{c}\text { GSTP1 (97\%), RARB (81\%), } \\
\text { RASSF1 (84\%) }\end{array}$ \\
\hline
\end{tabular}

PC: Prostate Cancer; PIN: Prostatic Intraepithelial Neoplasia. 
Urinary DNA methylation analysis for the screening of prostate cancer was first reported in 2000 by Goessl et al. [105]. They used the MSP method with a fluorescent labeled primer for methylation analyses. They analyzed the methylation status of GSTP1 in urine, plasma, serum, and ejaculate, of which the sensitivity of urinary GSTP1 methylation was 36\% and the specificity was $100 \%$. The same group later analyzed GSTP1 methylation in urine samples, which were obtained after a 15 to $30 \mathrm{~s}$ prostate massage [107]. Using this method, the sensitivity of GSTP1 methylation increased to 73\%. Moreover, when focusing on T1-2N0M0 patients, the sensitivity increased from $0 \%$ ( 0 of 11 patients) to $68 \%$ (15 of 22 patients). Hoque et al. [110] also analyzed urinary GSTP1 methylation using qMSP with eight other genes ( $p 16, A R F, M G M T, R A R \beta$, -cadherin, TIMP3, RASSF1A, and APC). The urine samples of age-matched individuals with no history of genitourinary malignancies were used as controls. The sensitivity and specificity of GSTP1 were $48 \%$ and $100 \%$, respectively. The panel of four genes ( $p 16, A R F, M G M T$, and GSTP1) could discriminate prostate cancer with a sensitivity and specificity of $87 \%$ and $100 \%$, respectively. In 2008 , Venar et al. [114] conducted a multicenter prospective study for patients with PSA levels higher than $2.5 \mathrm{ng} / \mathrm{mL}$. Urinary samples were collected after the DRE procedure. The methylation status of GSTP1, RAR $\beta 2$, and APC were analyzed. The sensitivity and specificity of three combined genes were $53-55 \%$ and $76-80 \%$, respectively. Another prospective study was conducted in 2009 for patients with PSA levels from 2 to $10 \mathrm{ng} / \mathrm{mL}$, which contained 178 prostate cancer patients and 159 noncancerous patients [112]. The sensitivity and specificity of the combination of three genes were $60 \%$ and $81 \%$, respectively. The specificities of these studies were lower than expected.

\section{Conclusions}

Several studies were conducted regarding cancer screening via the analysis of methylation in bodily fluids. In CRC screening, a higher sensitivity and specificity of stool DNA tests were reported and they can be used in clinical situations. In other cancers, there were no promising methylation markers that could be used in clinics. Some of the gene candidates, such as NID2 or TWIST1 in urinary DNA, seemed to be promising markers, however, these studies are denied in prospective studies $[86,98,100]$.

Most of the studies combined several genes in order to increase sensitivity, as the sensitivity of each gene was generally low. As the number of genes increased, the cost and time needed for the tests also will increase greatly. Simple and low-cost tests are required in cancer screening because it is performed for millions of people. To resolve this problem, a promising single methylation marker, which has a high sensitivity and specificity, needs to be explored.

Supplementary Materials: Supplementary materials can be found at www.mdpi.com/1422-0067/18/4/735/s1. Conflicts of Interest: The authors declare no conflict of interest.

\section{References}

1. Hegi, M.E.; Diserens, A.C.; Gorlia, T.; Hamou, M.F.; de Tribolet, N.; Weller, M.; Kros, J.M.; Hainfellner, J.A.; Mason, W.; Mariani, L.; et al. MGMT gene silencing and benefit from temozolomide in glioblastoma. N. Engl. J. Med. 2005, 352, 997-1003. [PubMed]

2. Katoh, H.; Yamashita, K.; Waraya, M.; Margalit, O.; Ooki, A.; Tamaki, H.; Sakagami, H.; Kokubo, K.; Sidransky, D.; Watanabe, M. Epigenetic silencing of HOPX promotes cancer progression in colorectal cancer. Neoplasia 2012, 14, 559-571. [CrossRef]

3. Yamashita, K.; Waraya, M.; Kim, M.S.; Sidransky, D.; Katada, N.; Sato, T.; Nakamura, T.; Watanabe, M. Detection of methylated CDO1 in plasma of colorectal cancer; a PCR study. PLoS ONE 2014, 9. [CrossRef] [PubMed]

4. Minatani, N.; Waraya, M.; Yamashita, K.; Kikuchi, M.; Ushiku, H.; Kojo, K.; Ema, A.; Nishimiya, H.; Kosaka, Y.; Katoh, H.; et al. Prognostic significance of promoter DNA hypermethylation of cysteine dioxygenase 1 (CDO1) gene in primary breast cancer. PLoS ONE. 2016, 11. [CrossRef] [PubMed] 
5. Ushiku, H.; Yamashita, K.; Kawamata, H.; Waraya, M.; Katoh, H.; Yokoi, K.; Tanaka, T.; Ishii, S.; Nishizawa, N.; Kikuchi, M.; et al. Homeobox-only protein expression is a critical prognostic indicator of pancreatic neuroendocrine tumor and is regulated by promoter DNA hypermethylation. Pancreas 2016, 45, 1255-1262. [CrossRef] [PubMed]

6. Wong, I.H.; Lo, Y.D.; Zhang, J.; Liew, C.T.; Ng, M.H.; Wong, N.; Lai, P.B.; Lau, W.Y.; Hjelm, N.M.; Johnson, P.J. Advances in brief detection of aberrant $p 16$ methylation in the plasma and serum of liver cancer patients. Cancer Res. 1999, 59, 71-73. [PubMed]

7. Lo, Y.D.; Chan, L.Y.; Lo, K.W.; Leung, S.F.; Zhang, J.; Chan, A.T.; Lee, J.C.; Hjelm, N.M.; Johnson, P.J.; Huang, D.P. Quantitative analysis of cell-free Epstein-Barr virus DNA in plasma of patients with nasopharyngeal carcinoma. Cancer Res. 1999, 59, 1188-1191. [PubMed]

8. Diehl, F.; Li, M.; Dressman, D.; He, Y.; Shen, D.; Szabo, S.; Diaz, L.A.; Goodman, S.N.; David, K.A.; Juhl, H.; et al. Detection and quantification of mutations in the plasma of patients with colorectal tumors. Proc. Natl. Acad. Sci. USA 2005, 102, 16368-16373. [CrossRef] [PubMed]

9. Stroun, M.; Lyautey, J.; Lederrey, C.; Olson-Sand, A.; Anker, P. About the possible origin and mechanism of circulating DNA apoptosis and active DNA release. Clin. Chim. Acta 2001, 313, 139-142. [CrossRef]

10. Bettegowda, C.; Sausen, M.; Leary, R.J.; Kinde, I.; Wang, Y.; Agrawal, N.; Bartlett, B.R.; Wang, H.; Luber, B.; Alani, R.M.; et al. Detection of circulating tumor DNA in early- and late-stage human malignancies. Sci. Transl. Med. 2014, 6. [CrossRef] [PubMed]

11. Cheng, F.; Su, L.; Qian, C. Circulating tumor DNA: A promising biomarker in the liquid biopsy of cancer. Oncotarget 2016, 7, 48832-48841. [CrossRef] [PubMed]

12. Anker, P.; Mulcahy, H.; Chen, X.Q.; Stroun, M. Detection of circulating tumour DNA in the blood (plasma/serum) of cancer patients. Cancer Metastasis Rev. 1999, 18, 65-73. [CrossRef] [PubMed]

13. Jahr, S.; Hentze, H.; Englisch, S.; Hardt, D.; Fackelmayer, F.O.; Hesch, R.D.; Knippers, R. DNA fragments in the blood plasma of cancer patients: Quantitations and evidence for their origin from apoptotic and necrotic cells. Cancer Res. 2001, 61, 1659-1665. [PubMed]

14. Dawson, S.J.; Tsui, D.W.; Murtaza, M.; Biggs, H.; Rueda, O.M.; Chin, S.F.; Dunning, M.J.; Gale, D.; Forshew, T.; Mahler-Araujo, B.; et al. Analysis of circulating tumor DNA to monitor metastatic breast cancer. N. Engl. J. Med. 2013, 368, 1199-1209. [CrossRef] [PubMed]

15. Siravegna, G.; Mussolin, B.; Buscarino, M.; Corti, G.; Cassingena, A.; Crisafulli, G.; Ponzetti, A.; Cremolini, C.; Amatu, A.; Lauricella, C.; et al. Clonal evolution and resistance to EGFR blockade in the blood of colorectal cancer patients. Nat. Med. 2015, 21, 795-801. [CrossRef] [PubMed]

16. Leary, R.J.; Kinde, I.; Diehl, F.; Schmidt, K.; Clouser, C.; Duncan, C.; Antipova, A.; Lee, C.; McKernan, K.; Francisco, M.; et al. Development of personalized tumor biomarkers using massively parallel sequencing. Sci. Transl. Med. 2010, 2. [CrossRef] [PubMed]

17. Leary, R.J.; Sausen, M.; Kinde, I.; Papadopoulos, N.; Carpten, J.D.; Craig, D.; O'Shaughnessy, J.; Kinzler, K.W.; Parmigiani, G.; Vogelstein, B.; et al. Detection of chromosomal alterations in the circulation of cancer patients with whole-genome sequencing. Sci. Transl. Med. 2012, 4. [CrossRef] [PubMed]

18. Dressman, D.; Yan, H.; Traverso, G.; Kinzler, K.W.; Vogelstein, B. Transforming single DNA molecules into fluorescent magnetic particles for detection and enumeration of genetic variations. Proc. Natl. Acad. Sci. USA 2003, 100, 8817-8822. [CrossRef] [PubMed]

19. Esposito, A.; Criscitiello, C.; Locatelli, M.; Milano, M.; Curigliano, G. Liquid biopsies for solid tumors: Understanding tumor heterogeneity and real time monitoring of early resistance to targeted therapies. Pharmacol. Ther. 2016, 157, 120-124. [CrossRef] [PubMed]

20. Qin, Z.; Ljubimov, V.A.; Zhou, C.; Tong, Y.; Liang, J. Cell-free circulating tumor DNA in cancer. Chin. J. Cancer 2016, 35. [CrossRef] [PubMed]

21. Kristensen, L.S.; Hansen, L.L. PCR-based methods for detecting single-locus DNA methylation biomarkers in cancer diagnostics, prognostics, and response to treatment. Clin. Chem. 2009, 55, 1471-1483. [CrossRef] [PubMed]

22. Taylor, K.H.; Kramer, R.S.; Davis, J.W.; et al. Ultradeep bisulfite sequencing analysis of DNA methylation patterns in multiple gene promoters by 454 sequencing. Cancer Res. 2007, 67, 8511-8518. [CrossRef] [PubMed]

23. Frommer, M.; McDonald, L.E.; Millar, D.S.; Collis, C.M.; Watt, F.; Grigg, G.W.; Molloy, P.L.; Paul, C.L. A genomic sequencing protocol that yields a positive display of 5-methylcytosine residues in individual DNA strands. Proc. Natl. Acad. Sci. USA 1992, 89, 1827-1831. [CrossRef] [PubMed] 
24. Herman, J.G.; Graff, J.R.; Myöhänen, S.; Nelkin, B.D.; Baylin, S.B. Methylation-specific PCR: A novel PCR assay for methylation status of CpG islands. Proc. Natl. Acad. Sci. USA 1996, 93, 9821-9826. [CrossRef] [PubMed]

25. Eads, C.A.; Danenberg, K.D.; Kawakami, K.; Saltz, L.B.; Blake, C.; Shibata, D.; Danenberg, P.V.; Laird, P.W. MethyLight: A high-throughput assay to measure DNA methylation. Nucleic Acids Res. 2000, $28, \mathrm{E} 32$. [CrossRef] [PubMed]

26. Li, M.; Chen, W.D.; Papadopoulos, N.; Goodman, S.N.; Bjerregaard, N.C.; Laurberg, S.; Levin, B.; Juhl, H.; Arber, N.; Moinova, H.; et al. Sensitive digital quantification of DNA methylation in clinical samples. Nat. Biotechnol. 2009, 27, 858-863. [CrossRef] [PubMed]

27. Rosas, S.L.; Koch, W.; da Costa Carvalho, M.D.; Wu, L.; Califano, J.; Westra, W.; Jen, J.; Sidransky, D. Promoter hypermethylation patterns of $p 16, \mathrm{O}^{6}$-methylguanine-DNA-methyltransferase, and death-associated protein kinase in tumors and saliva of head and neck cancer patients. Cancer Res. 2001, 61, 939-942. [PubMed]

28. Righini, C.A.; de Fraipont, F.; Timsit, J.F.; Faure, C.; Brambilla, E.; Reyt, E.; Favrot, M.C. Tumor-specific methylation in saliva: A promising biomarker for early detection of head and neck cancer recurrence. Clin. Cancer Res. 2007, 13, 1179-1185. [CrossRef] [PubMed]

29. Demokan, S.; Chang, X.; Chuang, A.; Mydlarz, W.K.; Kaur, J.; Huang, P.; Khan, Z.; Khan, T.; Ostrow, K.L.; Brait, M.; et al. KIF1A and EDNRB are differentially methylated in primary HNSCC and salivary rinses. Int. J. Cancer 2010, 127, 2351-2359. [CrossRef] [PubMed]

30. Pattani, K.M.; Zhang, Z.; Demokan, S.; Glazer, C.; Loyo, M.; Goodman, S.; Sidransky, D.; Bermudez, F.; Jean-Charles, G.; McCaffrey, T.; et al. Endothelin receptor type B gene promoter hypermethylation in salivary rinses is independently associated with risk of oral cavity cancer and premalignancy. Cancer Prev. Res. 2010, 3, 1093-1103. [CrossRef] [PubMed]

31. Carvalho, A.L.; Henrique, R.; Jeronimo, C.; Nayak, C.S.; Reddy, A.N.; Hoque, M.O.; Chang, S.; Brait, M.; Jiang, W.W.; Kim, M.M.; et al. Detection of promoter hypermethylation in salivary rinses as a biomarker for head and neck squamous cell carcinoma surveillance. Clin. Cancer Res. 2011, 17, 4782-4789. [CrossRef] [PubMed]

32. Rettori, M.M.; de Carvalho, AC.; Longo, A.L.; de Oliveira, C.Z.; Kowalski, L.P.; Carvalho, A.L.; Vettore, A.L. Prognostic significance of TIMP3 hypermethylation in post-treatment salivary rinse from head and neck squamous cell carcinoma patients. Carcinogenesis 2013, 34, 20-27. [CrossRef] [PubMed]

33. Schussel, J.; Zhou, X.C.; Zhang, Z.; Pattani, K.; Bermudez, F.; Jean-Charles, G.; McCaffrey, T.; Padhya, T.; Phelan, J.; Spivakovsky, S.; et al. EDNRB and DCC salivary rinse hypermethylation has a similar performance as expert clinical examination in discrimination of oral cancer/dysplasia versus benign lesions. Clin. Cancer Res. 2013, 19, 3268-3275. [CrossRef] [PubMed]

34. Carvalho, A.L.; Jeronimo, C.; Kim, M.M.; Henrique, R.; Zhang, Z.; Hoque, M.O.; Chang, S.; Brait, M.; Nayak, C.S.; Jiang, W.W.; et al. Evaluation of promoter hypermethylation detection in body fluids as a screening/diagnosis tool for head and neck squamous cell carcinoma. Clin. Cancer Res. 2008, 14, 97-107. [CrossRef] [PubMed]

35. Van Klaveren, R.J. Lung cancer screening. Eur. J. Cancer 2011, 47, S147-S155. [CrossRef]

36. Rivera, M.P.; Mehta, A.C.; Wahidi, M.M. Establishing the diagnosis of lung cancer: Diagnosis and management of lung cancer, 3rd ed: American college of chest physicians evidence-based clinical practice guidelines. CHEST J. 2013, 143, e142S-e165S. [CrossRef] [PubMed]

37. Belinsky, S.A.; Nikula, K.J.; Palmisano, W.A.; Michels, R.; Saccomanno, G.; Gabrielson, E.; Baylin, S.B.; Herman, J.G. Aberrant methylation of $p 16^{\mathrm{INK} 4 \mathrm{a}}$ is an early event in lung cancer and a potential biomarker for early diagnosis. Proc. Natl. Acad. Sci. USA 1998, 95, 11891-11896. [CrossRef] [PubMed]

38. Honorio, S.; Agathanggelou, A.; Schuermann, M.; Pankow, W.; Viacava, P.; Maher, E.R.; Latif, F. Detection of RASSF1A aberrant promoter hypermethylation in sputum from chronic smokers and ductal carcinoma in situ from breast cancer patients. Oncogene 2003, 22, 147-150. [CrossRef] [PubMed]

39. Konno, S.; Morishita, Y.; Fukasawa, M.; Shu, Y.; Wang, D.; Tanaka, R.; Minami, Y.; Iijima, T.; Noguchi, M. Anthracotic index and DNA methylation status of sputum contents can be used for identifying the population at risk of lung carcinoma. Cancer 2004, 102, 348-354. [CrossRef] [PubMed]

40. Cirincione, R.; Lintas, C.; Conte, D.; Mariani, L.; Roz, L.; Vignola, A.M.; Pastorino, U.; Sozzi, G. Methylation profile in tumor and sputum samples of lung cancer patients detected by spiral computed tomography: A nested case-control study. Int. J. Cancer 2006, 118, 1248-1253. [CrossRef] [PubMed] 
41. Belinsky, S.A.; Liechty, K.C.; Gentry, F.D.; Wolf, H.J.; Rogers, J.; Vu, K.; Haney, J.; Kennedy, T.C.; Hirsch, F.R.; Miller, Y.; et al. Promoter hypermethylation of multiple genes in sputum precedes lung cancer incidence in a high-risk cohort. Cancer Res. 2006, 66, 3338-3344. [CrossRef] [PubMed]

42. Shivapurkar, N.; Stastny, V.; Suzuki, M.; Wistuba, I.I.; Li, L.; Zheng, Y.; Feng, Z.; Hol, B.; Prinsen, C.; Thunnissen, F.B.; et al. Application of a methylation gene panel by quantitative PCR for lung cancers. Cancer Lett. 2007, 247, 56-71. [CrossRef] [PubMed]

43. Belinsky, S.A.; Grimes, M.J.; Casas, E.; Stidley, C.A.; Franklin, W.A.; Bocklage, T.J.; Johnson, D.H.; Schiller, J.H. Predicting gene promoter methylation in non-small-cell lung cancer by evaluating sputum and serum. Br. J. Cancer 2007, 96, 1278-1283. [CrossRef] [PubMed]

44. Shivapurkar, N.; Stastny, V.; Okumura, N.; Girard, L.; Xie, Y.; Prinsen, C.; Thunnissen, F.B.; Wistuba, I.I.; Czerniak, B.; Frenkel, E.; et al. Cytoglobin, the newest member of the globin family, functions as a tumor suppressor gene. Cancer Res. 2008, 68, 7448-7456. [CrossRef] [PubMed]

45. Guzmán, L.; Depix, M.S.; Salinas, A.M.; Roldán, R.; Aguayo, F.; Silva, A.; Vinet, R. Analysis of aberrant methylation on promoter sequences of tumor suppressor genes and total DNA in sputum samples: A promising tool for early detection of COPD and lung cancer in smokers. Diagn. Pathol. 2012, 7, 87. [CrossRef] [PubMed]

46. Leng, S.; Do, K.; Yingling, C.M.; Picchi, M.A.; Wolf, H.J.; Kennedy, T.C.; Feser, W.J.; Baron, A.E.; Franklin, W.A.; Brock, M.V.; et al. Defining a gene promoter methylation signature in sputum for lung cancer risk assessment. Clin. Cancer Res. 2012, 18, 3387-3395. [CrossRef] [PubMed]

47. Hubers, A.J.; van der Drift, M.A.; Prinsen, C.F.; Witte, B.I.; Wang, Y.; Shivapurkar, N.; Stastny, V.; Bolijn, A.S.; Hol, B.E.; Feng, Z.; et al. Methylation analysis in spontaneous sputum for lung cancer diagnosis. Lung Cancer 2014, 84, 127-133. [CrossRef] [PubMed]

48. Hubers, A.J.; Brinkman, P.; Boksem, R.J.; Rhodius, R.J.; Witte, B.I.; Zwinderman, A.H.; Heideman, D.A.; Duin, S.; Koning, R.; Steenbergen, R.D.; et al. Combined sputum hypermethylation and eNose analysis for lung cancer diagnosis. J. Clin. Pathol. 2014, 67, 707-711. [CrossRef] [PubMed]

49. Hubers, A.J.; Heideman, D.A.; Burgers, S.A.; Herder, G.J.; Sterk, P.J.; Rhodius, R.J.; Smit, H.J.; Krouwels, F.; Welling, A.; Witte, B.I.; et al. DNA hypermethylation analysis in sputum for the diagnosis of lung cancer: Training validation set approach. Br. J. Cancer 2015, 112, 1105-1113. [CrossRef] [PubMed]

50. Hulbert, A.; Torres, I.J.; Stark, A.; Chen, C.; Rodgers, K.; Lee, B.; Griffin, C.; Yang, A.; Huang, P.; Wrangle, J.; et al. Early detection of lung cancer using DNA promoter hypermethylation in plasma and sputum. Clin. Cancer Res. 2016. [CrossRef] [PubMed]

51. Mandel, J.S.; Bond, J.H.; Church, T.R.; Snover, D.C.; Bradley, G.M.; Schuman, L.M.; Ederer, F. Reducing mortality from colorectal cancer by screening for fecal occult blood. N. Engl. J. Med. 1993, 328, 1365-1371. [CrossRef] [PubMed]

52. Hardcastle, J.D.; Chamberlain, J.O.; Robinson, M.H.; Moss, S.M.; Amar, S.S.; Balfour, T.W.; James, P.D.; Mangham, C.M. Randomised controlled trial of faecal-occult-blood screening for colorectal cancer. Lancet 1996, 348, 1472-1477. [CrossRef]

53. Kronborg, O.; Fenger, C.; Olsen, J.; Jørgensen, O.D.; Søndergaard, O. Randomised study of screening for colorectal cancer with faecal-occult-blood test. Lancet 1996, 348, 1467-1471. [CrossRef]

54. Ahlquist, D.A.; Sargent, D.J.; Loprinzi, C.L.; Levin, T.R.; Rex, D.K.; Ahnen, D.J.; Knigge, K.; Lance, M.P.; Burgart, L.J.; Hamilton, S.R.; et al. Stool DNA and occult blood testing for screen detection of colorectal neoplasia. Ann. Intern. Med. 2008, 149, 441-450. [CrossRef] [PubMed]

55. Park, D.I.; Ryu, S.; Kim, Y.H.; Lee, S.H.; Lee, C.K.; Eun, C.S.; Han, D.S.; et al. Comparison of guaiac-based and quantitative immunochemical fecal occult blood testing in a population at average risk undergoing colorectal cancer screening. Am. J. Gastroenterol. 2010, 105, 2017-2025. [CrossRef] [PubMed]

56. Lee, J.K.; Liles, E.G.; Bent, S.; Levin, T.R.; Corley, D.A. Accuracy of fecal immunochemical tests for colorectal cancer: Systematic review and meta-analysis. Ann. Intern. Med. 2014, 160, 171-181. [CrossRef] [PubMed]

57. Van Rossum, L.G.; van Rijn, A.F.; Laheij, R.J.; van Oijen, M.G.; Fockens, P.; van Krieken, H.H.; Verbeek, A.L.; Jansen, J.B.; Dekker, E. Random comparison of guaiac and immunochemical fecal occult blood tests for colorectal cancer in a screening population. Gastroenterology 2008, 135, 82-90. [CrossRef] [PubMed] 
58. Parra-Blanco, A.; Gimeno-García, A.Z.; Quintero, E.; Nicolás, D.; Moreno, S.G.; Jiménez, A.; Hernández-Guerra, M.; Carrillo-Palau, M.; Eishi, Y.; López-Bastida, J. Diagnostic accuracy of immunochemical versus guaiac faecal occult blood tests for colorectal cancer screening. J. Gastroenterol. 2010, 45, 703-712. [CrossRef] [PubMed]

59. Müller, H.M.; Oberwalder, M.; Fiegl, H.; Morandell, M.; Goebel, G.; Zitt, M.; Mühlthaler, M.; Öfner, D.; Margreiter, R.; Widschwendter, M. Methylation changes in faecal DNA: A marker for colorectal cancer screening? Lancet 2004, 363, 1283-1285. [CrossRef]

60. Song, J.; Park, K.U.; Park, H.D.; Yoon, Y.; Kim, J.Q. High-throughput liquid chromatography-tandem mass spectrometry assay for plasma theophylline and its metabolites. Clin. Chem. 2004, 50, 2176-2179. [CrossRef] [PubMed]

61. Lenhard, K.; Bommer, G.T.; Asutay, S.; Schauer, R.; Brabletz, T.; Göke, B.; Lamerz, R.; Kolligs, F.T. Analysis of promoter methylation in stool: A novel method for the detection of colorectal cancer. Clin. Gastroenterol. Hepatol. 2005, 3, 142-149. [CrossRef]

62. Chen, W.D.; Han, Z.J.; Skoletsky, J.; Olson, J.; Sah, J.; Myeroff, L.; Platzer, P.; Lu, S.; Dawson, D.; Willis, J.; et al. Detection in fecal DNA of colon cancer-specific methylation of the nonexpressed vimentin gene. J. Natl. Cancer Inst. 2005, 97, 1124-1132. [CrossRef] [PubMed]

63. Huang, Z.H.; Li, L.H.; Yang, F.; Wang, J.F. Detection of aberrant methylation in fecal DNA as a molecular screening tool for colorectal cancer and precancerous lesions. World J. Gastroenterol. 2007, 13, 950-954. [CrossRef] [PubMed]

64. Zhang, W.; Bauer, M.; Croner, R.S.; Pelz, J.O.; Lodygin, D.; Hermeking, H.; Stürzl, M.; Hohenberger, W.; Matzel, K.E. DNA stool test for colorectal cancer: Hypermethylation of the secreted frizzled-related protein-1 gene. Dis. Colon Rectum. 2007, 50, 1618-1627. [CrossRef] [PubMed]

65. Wang, D.R.; Tang, D. Hypermethylated SFRP2 gene in fecal DNA is a high potential biomarker for colorectal cancer noninvasive screening. World J. Gastroenterol. 2008, 14, 524-531. [CrossRef] [PubMed]

66. Baek, Y.H.; Chang, E.; Kim, Y.J.; Kim, B.K.; Sohn, J.H.; Park, D.I. Stool methylation-specific polymerase chain reaction assay for the detection of colorectal neoplasia in Korean patients. Dis. Colon Rectum. 2009, 52, 1452-1463. [CrossRef] [PubMed]

67. Kim, M.S.; Louwagie, J.; Carvalho, B.; sive Droste, J.S.; Park, H.L.; Chae, Y.K.; Yamashita, K.; Liu, J.; Ostrow, K.L.; Ling, S.; et al. Promoter DNA methylation of oncostatin M receptor- $\beta$ as a novel diagnostic and therapeutic marker in colon cancer. PLoS ONE 2009, 4, e6555. [CrossRef] [PubMed]

68. Glöckner, S.C.; Dhir, M.; Yi, J.M.; McGarvey, K.E.; van Neste, L.; Louwagie, J.; Chan, T.A.; Kleeberger, W.; de Bruïne, A.P.; Smits, K.M.; et al. Methylation of TFPI2 in stool DNA: A potential novel biomarker for the detection of colorectal cancer. Cancer Res. 2009, 69, 4691-4699. [CrossRef] [PubMed]

69. Nagasaka, T.; Tanaka, N.; Cullings, H.M.; Sun, D.S.; Sasamoto, H.; Uchida, T.; Koi, M.; Nishida, N.; Naomoto, Y.; Boland, C.R.; et al. Analysis of fecal DNA methylation to detect gastrointestinal neoplasia. J. Natl. Cancer Inst. 2009, 101, 1244-1258. [CrossRef] [PubMed]

70. Hellebrekers, D.M.; Lentjes, M.H.; van den Bosch, S.M.; Melotte, V.; Wouters, K.A.; Daenen, K.L.; Smits, K.M.; Akiyama, Y.; Yuasa, Y.; Sanduleanu, S.; et al. GATA4 and GATA5 are potential tumor suppressors and biomarkers in colorectal cancer. Clin. Cancer Res. 2009, 15, 3990-3997. [CrossRef] [PubMed]

71. Melotte, V.; Lentjes, M.H.; van den Bosch, S.M.; Hellebrekers, D.M.; de Hoon, J.P.; Wouters, K.A.; Daenen, K.L.; Partouns-Hendriks, I.E.; Stessels, F.; Louwagie, J.; et al. N-Myc Downstream-Regulated Gene 4 (NDRG4): A candidate tumor suppressor gene and potential biomarker for colorectal cancer. J. Natl. Cancer Inst. 2009, 101, 916-927. [CrossRef] [PubMed]

72. Ahlquist, D.A.; Zou, H.; Domanico, M.; Mahoney, D.W.; Yab, T.C.; Taylor, W.R.; Butz, M.L.; Thibodeau, S.N.; Rabeneck, L.; Paszat, L.F.; et al. Next-generation stool DNA test accurately detects colorectal cancer and large adenomas. Gastroenterology 2012, 142, 248-256. [CrossRef] [PubMed]

73. Imperiale, T.F.; Ransohoff, D.F.; Itzkowitz, S.H.; Levin, T.R.; Lavin, P.; Lidgard, G.P.; Ahlquist, D.A.; Berger, B.M. Multitarget stool DNA testing for colorectal-cancer screening. N. Engl. J. Med. 2014, 370, 1287-1297. [CrossRef] [PubMed]

74. Zhang, H.; Zhu, Y.Q.; Wu, Y.Q.; Zhang, P.; Qi, J. Detection of promoter hypermethylation of Wnt antagonist genes in fecal samples for diagnosis of early colorectal cancer. World J. Gastroenterol. 2014, 20, 6329-6335. [CrossRef] [PubMed]

75. Têtu, B. Diagnosis of urothelial carcinoma from urine. Mod. Pathol. 2009, 2, S53-S59. [CrossRef] [PubMed] 
76. Chan, M.W.; Chan, L.W.; Tang, N.L.; Tong, J.H.; Lo, K.W.; Lee, T.L.; Cheung, H.Y.; Wong, W.S.; Chan, P.S.; Lai, F.M.; et al. Hypermethylation of multiple genes in tumor tissues and voided urine in urinary bladder cancer patients. Clin. Cancer Res. 2002, 8, 464-470. [PubMed]

77. Chan, M.W.; Chan, L.W.; Tang, N.L.; Lo, K.W.; Tong, J.H.; Chan, A.W.; Cheung, H.Y.; Wong, W.S.; Chan, P.S.; Lai, F.M.; et al. Frequent hypermethylation of promoter region of RASSF1A in tumor tissues and voided urine of urinary bladder cancer patients. Int. J. Cancer 2003, 104, 611-616. [CrossRef] [PubMed]

78. Friedrich, M.G.; Weisenberger, D.J.; Cheng, J.C.; Chandrasoma, S.; Siegmund, K.D.; Gonzalgo, M.L.; Toma, M.I.; Huland, H.; Yoo, C.; Tsai, Y.C.; et al. Detection of methylated apoptosis-associated genes in urine sediments of bladder cancer patients. Clin. Cancer Res. 2004, 10, 7457-7465. [CrossRef] [PubMed]

79. Sathyanarayana, U.G.; Maruyama, R.; Padar, A.; Suzuki, M.; Bondaruk, J.; Sagalowsky, A.; Minna, J.D.; Frenkel, E.P.; Grossman, H.B.; Czerniak, B.; et al. Molecular detection of noninvasive and invasive bladder tumor tissues and exfoliated cells by aberrant promoter methylation of laminin-5 encoding genes. Cancer Res. 2004, 64, 1425-1430. [CrossRef] [PubMed]

80. Dulaimi, E.; Uzzo, R.G.; Greenberg, R.E.; Al-Saleem, T.; Cairns, P. Detection of bladder cancer in urine by a tumor suppressor gene hypermethylation panel. Clin. Cancer Res. 2004, 10, 1887-1893. [CrossRef] [PubMed]

81. Yates, D.R.; Rehman, I.; Meuth, M.; Cross, S.S.; Hamdy, F.C.; Catto, J.W. Methylational urinalysis: A prospective study of bladder cancer patients and age stratified benign controls. Oncogene 2006, 25, 1984-1988. [CrossRef] [PubMed]

82. Hoque, M.O.; Begum, S.; Topaloglu, O.; Chatterjee, A.; Rosenbaum, E.; van Criekinge, W.; Westra, W.H.; Schoenberg, M.; Zahurak, M.; Goodman, S.N.; et al. Quantitation of promoter methylation of multiple genes in urine DNA and bladder cancer detection. J. Natl. Cancer Inst. 2006, 98, 996-1004. [CrossRef] [PubMed]

83. Urakami, S.; Shiina, H.; Enokida, H.; Kawakami, T.; Kawamoto, K.; Hirata, H.; Tanaka, Y.; Kikuno, N.; Nakagawa, M.; Igawa, M.; et al. Combination analysis of hypermethylated Wnt-antagonist family genes as a novel epigenetic biomarker panel for bladder cancer detection. Clin. Cancer Res. 2006, 12, 2109-2116. [CrossRef] [PubMed]

84. Yu, J.; Zhu, T.; Wang, Z.; Zhang, H.; Qian, Z.; Xu, H.; Gao, B.; Wang, W.; Gu, L.; Meng, J.; et al. A novel set of DNA methylation markers in urine sediments for sensitive/specific detection of bladder cancer. Clin. Cancer Res. 2007, 13, 7296-7304. [CrossRef] [PubMed]

85. Sun, J.; Chen, Z.; Zhu, T.; Yu, J.; Ma, K.; Zhang, H.; He, Y.; Luo, X.; Zhu, J. Hypermethylated SFRP1, but none of other nine genes "informative" for western countries, is valuable for bladder cancer detection in Mainland China. J. Cancer Res. Clin. Oncol. 2009, 135, 1717-1727. [CrossRef] [PubMed]

86. Renard, I.; Joniau, S.; van Cleynenbreugel, B.; Collette, C.; Naômé, C.; Vlassenbroeck, I.; Nicolas, H.; de Leval, J.; Straub, J.; van Criekinge, W.; et al. Identification and validation of the methylated TWIST1 and NID2 genes through real-time methylation-specific polymerase chain reaction assays for the noninvasive detection of primary bladder cancer in urine samples. Eur. Urol. 2010, 58, 96-104. [CrossRef] [PubMed]

87. Lin, H.H.; Ke, H.L.; Huang, S.P.; Wu, W.J.; Chen, Y.K.; Chang, L.L. Increase sensitivity in detecting superficial, low grade bladder cancer by combination analysis of hypermethylation of E-cadherin, p16, p14, RASSF1A genes in urine. Urol. Oncol. Semin. Orig. Investig. 2010, 28, 597-602. [CrossRef] [PubMed]

88. Eissa, S.; Swellam, M.; El-Khouly, I.M.; Kassim, S.K.; Shehata, H.; Mansour, A.; Esmat, M.; Nossier, A.I.; Hamdy, M.A.; Awad, N.M.; et al. Aberrant methylation of RAR $\beta 2$ and APC genes in voided urine as molecular markers for early detection of bilharzial and nonbilharzial bladder cancer. Cancer Epidemiol. Biomark. Prev. 2011, 20, 1657-1664. [CrossRef] [PubMed]

89. Reinert, T.; Modin, C.; Castano, F.M.; Lamy, P.; Wojdacz, T.K.; Hansen, L.L.; Wiuf, C.; Borre, M.; Dyrskjøt, L.; Ørntoft, T.F. Comprehensive genome methylation analysis in bladder cancer: Identification and validation of novel methylated genes and application of these as urinary tumor markers. Clin. Cancer Res. 2011, 17, 5582-5592. [CrossRef] [PubMed]

90. Vinci, S.; Giannarini, G.; Selli, C.; Kuncova, J.; Villari, D.; Valent, F.; Orlando, C. Quantitative methylation analysis of BCL2, hTERT, and DAPK promoters in urine sediment for the detection of non-muscle-invasive urothelial carcinoma of the bladder: A prospective, two-center validation study. Urol. Oncol. Semin. Orig. Investig. 2011, 29, 150-156. [CrossRef] [PubMed]

91. Chen, P.C.; Tsai, M.H.; Yip, S.K.; Jou, Y.C.; Ng, C.F.; Chen, Y.; Wang, X.; Huang, W.; Tung, C.L.; Chen, G.C.; et al. Distinct DNA methylation epigenotypes in bladder cancer from different Chinese sub-populations and its implication in cancer detection using voided urine. BMC Med. Genom. 2011, 4. [CrossRef] [PubMed] 
92. Serizawa, R.R.; Ralfkiær, U.; Steven, K.; Lam, G.W.; Schmiedel, S.; Schüz, J.; Hansen, A.B.; Horn, T.; Guldberg, P. Integrated genetic and epigenetic analysis of bladder cancer reveals an additive diagnostic value of FGFR3 mutations and hypermethylation events. Int. J. Cancer 2011, 129, 78-87. [CrossRef] [PubMed]

93. Costa, V.L.; Henrique, R.; Danielsen, S.A.; Eknaes, M.; Patrício, P.; Morais, A.; Oliveira, J.; Lothe, R.A.; Teixeira, M.R.; Lind, G.E.; et al. TCF21 and PCDH17 methylation: An innovative panel of biomarkers for a simultaneous detection of urological cancers. Epigenetics 2011, 6, 1120-1130. [CrossRef] [PubMed]

94. Chung, W.; Bondaruk, J.; Jelinek, J.; Lotan, Y.; Liang, S.; Czerniak, B.; Issa, J.P. Detection of bladder cancer using novel DNA methylation biomarkers in urine sediments. Cancer Epidemiol. Biomark. Prev. 2011, 20, 1483-1491. [CrossRef] [PubMed]

95. Reinert, T.; Borre, M.; Christiansen, A.; Hermann, G.G.; Ørntoft, T.F.; Dyrskjøt, L. Diagnosis of bladder cancer recurrence based on urinary levels of EOMES, HOXA9, POU4F2, TWIST1, VIM, and ZNF154 hypermethylation. PLoS ONE 2012, 7. [CrossRef] [PubMed]

96. Chihara, Y.; Kanai, Y.; Fujimoto, H.; Sugano, K.; Kawashima, K.; Liang, G.; Jones, P.A.; Fujimoto, K.; Kuniyasu, H.; Hirao, Y. Diagnostic markers of urothelial cancer based on DNA methylation analysis. BMC Cancer 2013, 13. [CrossRef] [PubMed]

97. Hayashi, M.; Bernert, H.; Kagohara, L.T.; Maldonado, L.; Brait, M.; Schoenberg, M.; Bivalacqua, T.; Netto, G.J.; Koch, W.; Sidransky, D.; et al. Epigenetic inactivation of VGF associated with Urothelial Cell Carcinoma and its potential as a non-invasive biomarker using urine. Oncotarget 2014, 5, 3350-3361. [CrossRef] [PubMed]

98. Abern, M.R.; Owusu, R.; Inman, B.A. Clinical performance and utility of a DNA methylation urine test for bladder cancer. Urol. Oncol. 2014, 32, 51.e21-51.e26. [CrossRef] [PubMed]

99. Yeh, C.M.; Chen, P.C.; Hsieh, H.Y.; Jou, Y.C.; Lin, C.T.; Tsai, M.H.; Huang, W.Y.; Wang, Y.T.; Lin, R.I.; Chen, S.S.; et al. Methylomics analysis identifies ZNF671 as an epigenetically repressed novel tumor suppressor and a potential non-invasive biomarker for the detection of urothelial carcinoma. Oncotarget 2015, 6, 29555-29572. [PubMed]

100. Fantony, J.J.; Abern, M.R.; Gopalakrishna, A.; Owusu, R.; Tay, K.J.; Lance, R.S.; Inman, B.A. Multi-institutional external validation of urinary TWIST1 and NID2 methylation as a diagnostic test for bladder cancer. Urol. Oncol. 2015, 33, 387.e1-387.e6. [CrossRef] [PubMed]

101. Roperch, J.P.; Grandchamp, B.; Desgrandchamps, F.; Mongiat-Artus, P.; Ravery, V.; Ouzaid, I.; Roupret, M.; Phe, V.; Ciofu, C.; Tubach, F.; et al. Promoter hypermethylation of HS3ST2, SEPTIN9 and SLIT2 combined with FGFR3 mutations as a sensitive/specific urinary assay for diagnosis and surveillance in patients with low or high-risk non-muscle-invasive bladder cancer. BMC Cancer 2016, 16. [CrossRef] [PubMed]

102. Dahmcke, C.M.; Steven, K.E.; Larsen, L.K.; Poulsen, A.L.; Abdul-Al, A.; Dahl, C.; Guldberg, P. A prospective blinded evaluation of urine-DNA testing for detection of urothelial bladder carcinoma in patients with gross hematuria. Eur. Urol. 2016, 70, 916-919. [CrossRef] [PubMed]

103. Catalona, W.J.; Partin, A.W.; Slawin, K.M.; Brawer, M.K.; Flanigan, R.C.; Patel, A.; Richie, J.P.; Walsh, P.C.; Scardino, P.T.; Lange, P.H.; et al. Use of the percentage of free prostate-specific antigen to enhance differentiation of prostate cancer from benign prostatic disease: A prospective multicenter clinical trial. JAMA 1998, 279, 1542-1547. [CrossRef] [PubMed]

104. Thompson, I.M.; Ankerst, D.P.; Chi, C.; Lucia, M.S.; Goodman, P.J.; Crowley, J.J.; Parnes, H.L.; Coltman, C.A. Operating characteristics of prostate-specific antigen in men with an initial PSA level of $3.0 \mathrm{ng} / \mathrm{mL}$ or lower. JAMA 2005, 294, 66-70. [CrossRef] [PubMed]

105. Goessl, C.; Krause, H.; Müller, M.; Heicappell, R.; Schrader, M.; Sachsinger, J.; Miller, K. Fluorescent methylation-specific polymerase chain reaction for DNA-based detection of prostate cancer in bodily fluids. Cancer Res. 2000, 60, 5941-5945. [PubMed]

106. Cairns, P.; Esteller, M.; Herman, J.G.; Schoenberg, M.; Jeronimo, C.; Sanchez-Cespedes, M.; Chow, N.H.; Grasso, M.; Wu, L.; Westra, W.B.; et al. Molecular detection of prostate cancer in urine by GSTP1 hypermethylation. Clin. Cancer Res. 2001, 7, 2727-2730. [PubMed]

107. Goessl, C.; Müller, M.; Heicappell, R.; Krause, H.; Straub, B.; Schrader, M.; Miller, K. DNA-based detection of prostate cancer in urine after prostatic massage. Urology 2001, 58, 335-338. [CrossRef]

108. Goessl, C.; Muller, M.; Heicappell, R.; Krause, H.; Miller, K. DNA-based detection of prostate cancer in blood, urine, and ejaculates. Ann. N. Y. Acad. Sci. 2001, 945, 51-58. [CrossRef] [PubMed]

109. Jernimo, C.; Usadel, H.; Henrique, R.; Silva, C.; Oliveira, J.; Lopes, C.; Sidransky, D. Quantitative GSTP1 hypermethylation in bodily fluids of patients with prostate cancer. Urology 2002, 60, 1131-1135. [CrossRef] 
110. Hoque, M.O.; Topaloglu, O.; Begum, S.; Henrique, R.; Rosenbaum, E.; van Criekinge, W.; Westra, W.H.; Sidransky, D. Quantitative methylation-specific polymerase chain reaction gene patterns in urine sediment distinguish prostate cancer patients from control subjects. J. Clin. Oncol. 2005, 23, 6569-6575. [CrossRef] [PubMed]

111. Rouprêt, M.; Hupertan, V.; Yates, D.R.; Catto, J.W.; Rehman, I.; Meuth, M.; Ricci, S.; Lacave, R.; Cancel-Tassin, G.; de la Taille, A.; et al. Molecular detection of localized prostate cancer using quantitative methylation-specific PCR on urinary cells obtained following prostate massage. Clin. Cancer Res. 2007, 13, 1720-1725. [CrossRef] [PubMed]

112. Baden, J.; Green, G.; Painter, J.; Curtin, K.; Markiewicz, J.; Jones, J.; Astacio, T.; Canning, S.; Quijano, J.; Guinto, W.; et al. Multicenter evaluation of an investigational prostate cancer methylation assay. J. Urol. 2009, 182, 1186-1193. [CrossRef] [PubMed]

113. Daniunaite, K.; Jarmalaite, S.; Kalinauskaite, N.; Petroska, D.; Laurinavicius, A.; Lazutka, J.R.; Jankevicius, F. Prognostic value of RASSF1 promoter methylation in prostate cancer. J. Urol. 2014, 192, 1849-1855. [CrossRef] [PubMed]

114. Vener, T.; Derecho, C.; Baden, J.; Wang, H.; Rajpurohit, Y.; Skelton, J.; Mehrotra, J.; Varde, S.; Chowdary, D.; Stallings, W.; et al. Development of a multiplexed urine assay for prostate cancer diagnosis. Clin. Chem. 2008, 54, 874-882. [CrossRef] [PubMed]

(C) 2017 by the authors. Licensee MDPI, Basel, Switzerland. This article is an open access article distributed under the terms and conditions of the Creative Commons Attribution (CC BY) license (http:/ / creativecommons.org/licenses/by/4.0/). 